School of Finance

University of St.Gallen

Cultural Preferences and the Choice BetWeen FORMAL AND INFORMAL FINANCING

MASCIA BEDENDO

EMILIA GARCIA-APPENDINI

LINUS SIMING

WORKING PAPERS ON FinANCE No. 2017/07

SWISS INSTITUTE OF BANKING AND FINANCE (S/BF - HSG)

MAY 2017 


\title{
Cultural preferences and the choice between formal and informal financing
}

\author{
Mascia Bedendo ${ }^{\mathrm{a}}$ \\ Emilia Garcia-Appendini ${ }^{\mathrm{b}}$ \\ Linus Siming ${ }^{\mathrm{a}}$
}

May 2017

\begin{abstract}
This paper documents significant differences in the financing structure of small firms with managers of diverse cultural backgrounds. To separate the effect of culture from other factors that affect the financing structure of firms, we exploit cultural heterogeneity within a geographical area with shared regulations, institutions, and macroeconomic cycles. Our findings suggest that there exist significant differences in the culturally embedded preferences towards the use of formal and informal sources of financing (bank loans and trade credit). Our results are robust to alternative explanations based on potential differences in credit constraints and in the distribution of cultural origins across industrial sectors, trading partners, and headquarters location.
\end{abstract}

JEL classification: Z10, G32, M14

Keywords: Managerial cultural origin, Informal financing, Trade credit, Small firm financing

\footnotetext{
a Audencia Business School, 8 route de la Jonelière 44312 Nantes, France; ${ }^{\mathrm{b}}$ St Gallen University, Unterer Graben 21, CH-9000 St Gallen, Switzerland. We thank Martin Brown, Luigi Guiso, Per Östberg, Alexander Wagner, and seminar participants at Leeds University Business School, Strathclyde Business School, the $10^{\text {th }}$ Swiss Winter Conference on Financial Intermediation in Lenzerheide, the $20^{\text {th }}$ Annual Conference of the Swiss Society for Financial Market Research in Zürich for helpful comments, and Constantin Charles and Kristian Blickle for research assistance. We thank ASTAT and ISTAT for providing data on imports to South Tyrol. We gratefully acknowledge financial support from the Audencia Foundation.
} 


\section{Introduction}

An influential body of literature stemming from the seminal study of Bertrand and Schoar (2003) has documented that individual characteristics of firm managers represent significant determinants of firm policies. In this paper we focus on one specific characteristic of managers, their cultural origin, and investigate how it affects the financing decisions of the firms they run. The impact of the cultural background of individuals on their own financial decisions is well established in the literature. Guiso et al. (2004) argue that individuals who live in areas characterized by higher social capital are more likely to hold stocks and access bank credit, and less likely to use cash and borrow from family and friends. By proxying cultural origin with language, Chen (2013) finds that individuals who speak languages with weak future-time reference (such as German or Japanese) save more than individuals with strong futuretime reference (such as English, French, or Italian). Following the predictions of the managerial-style literature, we ask to what extent the financial preferences of managers-as shaped by their cultural origin — carry through into firm financial policies.

The empirical identification of the effect of management's cultural traits on firm financing decisions is challenging, because firms of different cultural backgrounds are usually headquartered in countries with diverse regulation and different macroeconomic, geographic, and institutional settings. Being able to distinguish the role played by the cultural background of the manager from the role played by those other factors is crucial, as differences in economic conditions (i.e., interest rates, inflation, or expectations about the business cycle), incentives provided by institutions and regulation (i.e., tax incentives), and geographic considerations (such as proximity to financial institutions) have been shown to affect financing choices. We overcome this empirical challenge by exploiting cultural differences within a geographical area that shares a common regulatory, institutional, and macroeconomic setting: The autonomous province of South Tyrol in Northern Italy.

The South Tyrol province in Italy represents an excellent natural laboratory to assess whether differences in the cultural origin of firm managers affect firm financing choices. One of the richest areas in Italy and in the European Union, South Tyrol is home to individuals who belong to two main cultural groups: Italian and Germanic. ${ }^{1}$ Both groups share a common Catholic religious background and live next to each other within municipalities. However, they lead relatively segregated social lives: Children attend separate schools and individuals of Germanic (Italian) origin interact and socialize mostly with Germanic (Italian) peers (Sutter et al., 2015; Angerer et al., 2016). Notably, the two cultures differ significantly along several dimensions that could affect financing choices. Simply by referring to linguistic differences, we note that the German word for debt is "Schuld" (meaning fault or guilt) and

\footnotetext{
${ }^{1}$ With "Germanic culture" we refer to people who speak German or a regional version of standard German.
} 
that German and Italian languages differ in their degree of future-time reference. Importantly for our study, the province includes a large number of firms from a wide range of industry sectors, all subject to the same institutional environment and legal framework. Moreover, most of the firms in the province are small and owner-managed, which obviates any agency problems.

In line with Guiso et al. (2006), we define culture as "those customary beliefs and values that ethnic, religious, and social groups transmit fairly unchanged from generation to generation". Throughout our analysis, we proxy the cultural origin of firm managers with their names, under the assumption that managers with a Germanic (Italian) name share a common language. Consistently with the above definition, our premise is that speaking the same language is a necessary condition for social interaction and for spreading cultural values. Through a common language, parents transmit their beliefs and preferences vertically to their children and, similarly, peers transmit their values horizontally to other peers. Accordingly, we classify all managers of firms headquartered in South Tyrol as of Germanic or Italian origin based on their given names and surnames. Our approach is similar to the one in Grinblatt and Keloharju (2001), who also use a classification based on names to achieve intra-country cultural identification across two distinct language families.

We find significant differences with respect to financing decisions between firms that are managed by individuals with an Italian cultural background and firms managed by individuals with a Germanic cultural background. Firms run by managers from the former group are less capitalized than firms run by individuals from the latter group. This, however, does not translate into higher levels of bank loans. Instead, we show that firms led by individuals from the Italian cultural group resort significantly more to trade credit than companies run by individuals from the Germanic cultural group. Consistently, we observe that they are also willing to lend more credit to their customers. Thus, our findings document a positive and significant association between the presence of a manager of Italian cultural origin and the use of more informal firm financing channels. These results are in line with a well-documented difference between individuals of Germanic and Italian origin, i.e. their preference for interacting within formal institutions as opposed to more informal networks (Bandiera et al., 2010; Puntscher et al., 2014, Becker et al., 2016).

By construction, our setup allows us to exclude the possibility that our findings are due to differences in institutional or macroeconomic conditions. In a series of robustness tests, we rule out further endogeneity concerns. Our results are not explained away when controlling for financial constraints and availability of bank credit to firms of different cultural groups (both in normal times and during the financial and sovereign crisis), nor by an endogenous sorting of managers of different cultural origin with certain firm characteristics. Our results, in fact, continue to hold (i) within the more homogeneous sample of family firms that are managed by a family member; (ii) within the more homogeneous 
subsample of micro firms; (iii) by excluding industry sectors that have a high concentration of individuals of a single cultural group; (iv) by excluding industry sectors that import the most and, hence, may differ in the terms of trade credit. Our results also hold on subsamples of firms that have been matched on size, industry, and location. Finally, to reinforce our interpretation of the existence of a causal link between culture and financing choices, we adopt an instrumental variable approach. Our instrument identifies the exogenous component of the cultural origin of the firms' manager by exploiting historical and geographical circumstances within the South Tyrol province that led to a larger concentration of the population of Italian origin in certain valleys and areas. Our findings consistently show that firms managed by an individual of Italian origin rely more intensively on informal sources of finance. We conclude that managers from seemingly close cultures that live side-by-side can nevertheless display large and important differences in basic corporate financing decisions.

Our paper contributes to the fast-growing literature that analyzes the impact of culture on firm policies. As discussed extensively in Karolyi (2016), many of these studies rely on cross-country differences in cultural traits that affect financial choices. Examples in corporate finance include studies linking culture with corporate risk taking ( $\mathrm{Li}$ et al., 2015), corporate governance (Griffin et al., 2017), firm performance (Frijns et al., 2016), or firm financing (Chui et al, 2002; El Ghoul and Zheng, 2016; Levine et al., 2016). Cross-country comparisons are, however, unable to fully control for differences in regulatory, institutional, and economic settings. Our method follows a more recent strand of the literature that relies on an epidemiological approach, which attempts to separate culture from the environment by studying outcome variables of individuals whose cultures differ, but in a common economic and institutional setting (Fernández, 2011). In this respect, this method is superior in dealing with omitted variables. In a corporate finance setup, studies that use this approach include Delis et al. (2017), Nguyen et al. (2017), and Pan et al. (2016).

The papers most closely related to ours are by El Ghoul and Zheng (2016) and Levine et al. (2016), who rely on cross-country differences in the Hofstede measures and in trust, respectively, to study the relation between culture and the use of trade credit. As mentioned above, our approach allows us to separate the effect of culture from the effect of heterogeneous institutional and regulatory structures, contract enforcement, and trade credit payment practices present in different countries. Our particular setup, in which individuals share a common Catholic faith, further rules out that religion, commonly associated with culture, is driving our results. More importantly, our approach enables us to contribute to this literature by uncovering an additional dimension that can also explain differences in the use of trade credit across different cultures, i.e. preferences. In fact, while Hofstede scores for the population of South Tyrol are unavailable, the scores for Austria and Italy, which are the closest countries to our 
Germanic and Italian cultural groups, are fairly similar. ${ }^{2}$ Such differences in the Hofstede's metrics by themselves would not be sufficient to explain differences in the recourse to trade credit. In a similar way, trust by itself cannot explain the higher use of trade credit in firms managed by CEOs of Italian origin. As a matter of fact, according to Levine et al. (2016), the higher level of observed trustfulness of Austrians relative to Italians should translate into a more intense recourse of firms with a manager of Germanic origin to informal financing during a financial crisis, which is not supported by our empirical observations. ${ }^{3}$ Thus, our intra-country setting enables us to provide evidence that additional measures of preferences linked to culture can also affect the firms' financing structure.

Our findings also contribute to the trade credit literature, by providing an additional explanation to the recourse to this type of financing in the presence of specialized financial intermediaries (Petersen and Rajan, 1997; Giannetti et al., 2011). The theoretical literature has mostly focused on transaction costs or information asymmetries to justify the co-existence of formal bank credit and informal trade credit. ${ }^{4}$ Our findings suggest an additional explanation: The higher recourse to trade credit could simply reflect personal, culturally founded, preferences towards this informal source of financing.

\section{Institutional Background}

In 1915, the Triple Entente-United Kingdom, France, and Russia—signed a treaty with Italy, which stipulated that Italy should abandon its alliance with Germany and Austria-Hungary (the Triple Alliance) and instead join the war on the side of the Entente. In return, Italy was promised a number of territorial gains following the ultimate defeat of the German and Austro-Hungarian empires. Subsequently, in

\footnotetext{
${ }^{2}$ According to the Hofstede measures, both Austria and Italy are classified as countries with low power distance, high individualism, high masculinity, high preference for uncertainty avoidance, high long term orientation, and they only differ in terms of indulgence (with Austria being indulgent and Italy being non-indulgent). See https://geert-hofstede.com/countries.html.

${ }^{3}$ Calculations performed by the authors using data from the European Value Survey (2008-2010), to which both Austria and Italy took part, show that Austrians have significantly higher trust than Italians (at a $1 \%$ significance level). The generalized level of trust is measured with the percentage of respondents answering positively to the question "Most people can be trusted". See http://www.europeanvaluesstudy.eu/.

${ }^{4}$ Transaction costs theories of trade credit include Ferris (1981), Brick and Fung (1984), Emery (1984), Daripa and Nilsen (2011), among others. Examples of theories that motivate the existence of trade credit through information asymmetries include Lee and Stowe (1993), Smith (1987), Biais and Gollier (1997), Burkart and Ellingsen (2004), and Cuñat (2007).
} 
1919, Austria ceded South Tyrol to Italy with the Treaty of Saint-Germain-en-Laye, thereby ending hundreds of years of Habsburg rule in the province.

At the time of its annexation, $89 \%$ of the population spoke German, 3\% spoke Italian, and the remainder of the population spoke either Ladin or other languages of the Empire (Benvenuto, 2007). This was however to quickly change. In 1923, the fascist government initiated the "Italianization" of South Tyrol, which included a series of measures and economic incentives aimed at favoring the relocation of Italians from other parts of Italy to South Tyrol. During this period, the majority of German schools were closed and Italian was declared the only official language of the province.

Following the Second World War, the region of Trentino-Alto Adige (which includes the provinces of Trento and South Tyrol) was granted a special autonomous status, German and Italian were both recognized as official languages, incentives in favor of Italians were formally removed, and Germanlanguage education was re-introduced. However, since Italians were still the majority at the regional level, self-government of the Germanic minority was not possible until 1972, when the province of South Tyrol was explicitly granted an autonomous status. The 1972 agreement guarantees equal rights and opportunities to South Tyroleans of both language groups, and grants considerable legislative and executive independence from the national government in most matters of economic and social affairs.

As of the last census in year 2011 (ASTAT, 2015), 70\% out of roughly half a million inhabitants in the South Tyrol reported German as their mother tongue, 26\% reported Italian as their main language, and $4 \%$ identified themselves as Ladin speakers. The map in Figure 1 illustrates the linguistic composition of South Tyrol. The majority of the municipalities in South Tyrol are predominantly German speaking, although there is a large variation in the percentage of Italian speakers across towns ranging from 73\% in the city of Bolzano to $0 \%$ in Martello, a town in the northwestern Vinschgau region that borders with Austria and Switzerland. As a consequence of the "Italianization" process, the largest concentration of Italian speakers is located close to the cities of Bolzano and Merano. Although municipalities differ considerably on the proportion of Italian-speaking population, there is no geographic segregation between citizens within municipalities.

\section{Research Design}

Our research design follows the epidemiological method (described extensively in Fernández, 2011), which aims to separate culture from the environment by studying the outcomes of individuals from different cultures who share a common economic and institutional setting. This approach presents obvious advantages in controlling for omitted variables and endogeneity compared to more standard methods such as the use of cross-country regressions. The epidemiological method is well suited for our 
purposes since South Tyroleans are all exposed to an identical economic and institutional environment and differ only in terms of belonging either to the Germanic or Italian culture. We want to assess the impact of managers' cultural origin on firm financing and trace the effect of culture through the economic channel that we conjecture it should affect: Different preferences regarding the sources of financing. To do so - and at the same time prevent cultural explanations from becoming simple ex-post rationalizations and reduce the risk of spurious correlations-we follow a tree-step procedure described as follows.

\subsection{Step one: Hypothesis development}

Our first step is to argue that individuals in South Tyrol belonging to the Germanic culture on one hand, and the Italian culture on the other hand, differ on their preferences towards different sources of financing. This link can be deduced from several studies, empirical observations, and anecdotal evidence.

First of all, individuals of Italian and Germanic origin differ regarding their view of taking up debt, in general. In fact, the German word for debt is "Schuld", which can be translated into English as "fault" or "guilt". This morally charged term contrasts with the more neutral Italian word for debt, "debito", stemming from the Latin word "debere" which simply means "to owe something". Consistently with an overall negative view of debt, there is anecdotal evidence that borrowing for consumption purposes is often frowned upon in German-speaking countries. Thus, it is natural to assume that Italian-speaking individuals would favor a financing structure that relies relatively more on debt than German-speaking individuals.

Language itself could also shape individuals' preference towards particular forms of financing. Chen (2013) finds that speaking a language in which future actions are typically expressed in present tense (i.e. weak future time-reference languages, such as German) tends to correlate positively with futureoriented behavior such as saving, having a retirement account, exercising, or not smoking. The hypothesis is that languages, such as German, that grammatically equate the present and future make speakers more aware that the choices made in the present affect the future. In contrast, speakers of strong future time-reference languages such as Italian would tend to dissociate the present from the future. While the author did not explore the correlation with time-reference languages and debt taking, it is natural to extend this reasoning and expect German-speaking individuals to favor financing expenditures out of presently available savings or retained earnings, rather than relying on uncertain future earnings. As before, this argument suggests that Italian-speaking individuals should favor a financing structure that relies relatively more on debt, and less on equity capital, than German-speaking individuals. 
Individuals of Italian and Germanic origin can also differ regarding their preference towards formal and informal financing. Becker et al. (2016) study whether the cultural norms originating in the Habsburg Empire still endure today. They find that the Habsburg Empire, with its well-respected administration, increased citizens' liking of formal institutions, and that these preferences persist today among the descendants living in the 17 countries that used to be the territory of the Habsburg Empire. Puntscher et al. (2014) document that individuals of Italian origin living in South Tyrol state a stronger preference for informal friendship ties and a weaker preference for organizing themselves and interacting through formal associations compared to South Tyroleans of Germanic origin. All in all, these two studies suggest that South Tyroleans from the Italian (Germanic) cultural group have a preference for informal (formal) institutions. In a similar vein, Bandiera et al. (2010) find that there is a preference in Italy to hire managers through informal channels such as personal or family contacts, rather than formal channels like business contacts or head hunters.

Guiso et al. (2004) directly link financial development-i.e. the reliance on formal rather than informal financing - to the level of social capital. Since social capital is an important determinant of the level of trust, and trust is a necessary condition for the development of financial markets, social capital should also affect the level of financial development. By exploiting social capital differences at the province level in Italy (measured as participation in referenda and blood donations), they show that households located in high-social-capital areas make more (less) use of institutional (informal) credit. Data on households' recourse to bank and informal financing are not available at intra-province level, making it difficult to directly test whether South Tyroleans of Italian and Germanic origin differ in their financing habits. However, a number of elements suggest that individuals of Germanic culture may be characterized by higher levels of social capital and trust. Puntscher et al. (2014) conduct a survey in the South Tyrol province and report higher levels of generalized trust in German-speaking citizens. Similar to Guiso et al. (2004), in an untabulated analysis we explore the participation in referenda and find a positive correlation of $45.5 \%$ between the proportion of German-speaking population in the municipalities in South Tyrol according to the 2011 census and the participation to the referendum that took place in the same year. Given the link between social capital/trust and financial development, we can then expect South Tyroleans from the Italian (Germanic) cultural group to have a preference for informal (formal) financing.

Finally, the literature on managerial style predicts that managers' individual traits and preferences (including those arising from culture) are likely to affect the decisions they take concerning not only their household, but also their firms. Thus, based on the above arguments, we derive our main hypotheses: (i) Firm managers from the Italian cultural group are more likely to resort to debt relative to firm managers of the Germanic cultural group, and (ii) managers from the Italian cultural group are 
more likely to resort to informal forms of financing, such as trade credit, compared to managers from the Germanic cultural group, who instead should be more likely to finance their firms through formal means of financing, such as bank loans.

\subsection{Step two: Classification of the manager's cultural origin}

The second step consists of classifying the firm managers into their cultural group. We start by selecting firms headquartered in the South Tyrol province with data available on Orbis-Bureau van Dijk. Given that Italian law requires such companies to file and deposit annual reports with the local Chamber of Commerce, this set of firms includes essentially all the limited liability firms (Societa' per Azioni and Societa' a Responsabilita' Limitata) headquartered in the province. Through the NACE industry classification code, we exclude financial and real estate companies, due to their peculiar capital and debt structure. For the remaining sample firms, we retrieve the latest available data on the board composition (as of March 2016), and identify the CEO.

To establish whether the CEO is of Germanic or Italian cultural origin we proceed as follows. We utilize search algorithms that identify the most common: Germanic surnames; Germanic male given names; Germanic female given names; Italian surnames; Italian male given names; Italian female given names. ${ }^{5}$ Subsequently, a CEO is classified as having a Germanic cultural origin if all his/her given names and surname can be found in the Germanic listings, while he/she is classified as having an Italian cultural origin if given names and surname are in the Italian lists. We require that both the given name and the surname are Germanic (Italian) for a CEO to be associated with a Germanic (Italian) origin. We manually double-check the allocation of CEOs to the two categories to ensure that such requirement is satisfied. In comparison to alternative classification criteria based only on the first name or on the surname, our approach enables us to achieve a neater identification of the origin of managers and reduce potential misclassification bias due, for example, to bilingual families. Bilingual families may lead to misclassification to the extent that managers whose parents speak different languages cannot be easily associated with one of the two cultures. Given that bilingual families are most likely to manifest

\footnotetext{
5 We retrieve Italian surnames from http://www.cognomix.it/origine-cognomi-italiani, which lists the most common Italian surnames explaining their origin. We obtain German and Austrian surnames, respectively, from https://de.wiktionary.org/wiki/Verzeichnis:Deutsch/Liste_der_h\%C3\%A4ufigsten_Nachnamen_Deutschlands and https://de.wiktionary.org/wiki/Verzeichnis:Deutsch/Liste_der_h\%C3\%A4ufigsten_Nachnamen_\%C3\%96sterreichs, which are based on telephone directories of the countries and were manually cleaned to eliminate foreign last names. Finally, first names come from http://www.vornamen-weltweit.de/maennlich-deutsch.php, http://www.vornamenweltweit.de/weiblich-deutsch.php, and http://www.vornamen-weltweit.de/geographisch.php?land=4 .
} 
themselves through mixed names (e.g., a Germanic first name and an Italian surname), constraining both names and surname of the manager to be of the same linguistic origin should minimize such instances. Our classification criterion is not overly restrictive, as only 5.8\% of the managers in our sample firms have a discordant Germanic (Italian) first name and Italian (Germanic) surname. ${ }^{6}$ Since we are interested in comparing the features of firms run by managers of Germanic and Italian origins, we discard managers with a different linguistic origin, which account for $2.1 \%$ of the sample firms. Some examples of how we have classified managers are provided in Appendix A.

\subsection{Step three: Impact of the manager's culture on firm financing}

The third and final step of our research approach is to show that the preference stated by South Tyroleans of Italian origin for informal versus formal networks, institutions, and financing has an impact on the firm' choices of financing channels when the firm manager is of Italian origin. We do so by regressing a number of firm financing outcome variables on the manager's cultural origin indicator obtained above.

Our regression analysis exploits the cross-sectional variation in managers' culture and firm financing structure. We obtain information about the financing structure from Orbis. This database provides only the latest available information on the composition and characteristics of the top management of a firm. For consistency, in our main analyses we extract only the latest financial statements available (as of March 2016) for our sample firms. This ensures that the firm financial variables we look at refer to a time period when the manager was in charge of the company. ${ }^{7}$

Table 1 reports basic summary statistics on the cross section of our sample firms. Our key variable is the indicator variable $C E O$ of Italian origin, which takes a value of one if the manager is classified as of Italian origin, and zero if he/she is classified as of Germanic origin. On average, $29.5 \%$ of the managers in the sample are of Italian origin. This is in line with the overall percentage of Italian-speaking population in South Tyrol, which was equal to $26.1 \%$ according to the 2011 Census (ASTAT, 2015). None of the firms in the sample is publicly traded and only $2.8 \%$ are large firms according to the definitions provided by the European Commission (i.e. turnover larger than $50 \mathrm{~m}$ euros or total assets larger than $43 \mathrm{~m}$ euros). To compare the financing structure of firms we use the following ratios: Total

\footnotetext{
${ }^{6}$ For robustness, we repeat our analysis by classifying the linguistic origin of CEOs on the basis of (i) their first name only, and (ii) their surname only. The results, available from the authors upon request, are qualitatively unchanged.

${ }^{7}$ As we shall see below, all of the firms in the sample are privately held and most of them are small or micro firms. As a result, the cultural origin of the management of the company is unlikely to change over a relatively small time horizon. For robustness, in Section 5.2 we also exploit the panel dimension of the Orbis data.
} 
liabilities over total assets, as a measure of all debts the company is liable for; total debt over total assets, as a measure of recourse to formal financing (i.e. bank loans); and accounts payable over total assets as a measure of recourse to informal financing (i.e. trade credit). These will be the main dependent variables in our analysis. The financing structure of our firms is therefore very simplified and consists essentially of equity, bank loans and trade credit. ${ }^{8}$ To complement our analysis, we also include two variables to analyze the asset structure of the firms' balance sheet: Cash over total assets, and accounts receivable over total assets, as a measure of how much credit a firm provides to its clients.

In Table 2 we compare the balance sheet structure of firms led by managers of Italian and Germanic origins by means of a standard two-sample t-test for differences in means. Our findings suggest that firms run by managers of Italian culture are less capitalized than firms run by managers of Germanic culture. However, this does not seem to translate into a larger recourse to traditional sources of debt, as indicated by a lower debt ratio. Instead, these firms are characterized by a higher usage of more informal sources of funding, such as trade credit (and debit). The two sets of companies also differ along other dimensions. Compared to their Germanic-led counterparties, firms with a manager of Italian origin, on average, grow at a slower speed, are smaller and younger, hold more cash, have a lower share of tangible assets, and are led by managers who are older and more likely to be female.

\section{Main Results}

In the remainder of the paper, we shift our analysis to a multivariate setting. Table 3 reports the estimates from OLS regressions where the dependent variables measure the firms' liability and asset structure. In all specifications, we add a set of standard control variables that previous literature has found to be significant determinants of firm capital structure. Firm-specific controls include: Size, asset tangibility, sales growth, capital expenditures, operating margin, and age. We also add some manager-specific variables to account for manager characteristics, other than the linguistic origin, that may impact capital and debt structure choices, i.e. age, age squared, and an indicator variable that takes a value of one if the manager is male and zero if female. Details on how dependent and control variables are calculated are in Appendix B. All continuous variables in our analyses are winsorized at the $1 \%$ and $99 \%$ levels to minimize the impact of outliers. Also, we use beginning-of-the-year values for our balance sheet control variables to mitigate endogeneity concerns. Although our sample is cross-sectional, we add year fixed effects to account for the fact that the latest year of available balance sheet data is not the same for all

\footnotetext{
${ }^{8}$ Consistently with these findings, Giannetti (2003) documents that trade credit is important for unlisted firms.
} 
sample firms. Finally, we employ industry fixed effects, computed according to the 21 NACE classification groups, to capture industry-specific differences in the firm financing structure.

The results in Table 3 confirm the univariate findings that firms run by managers of Italian cultural origin are less capitalized than firms run by individuals of Germanic cultural origin. However, this difference does not translate into higher levels of bank loans, as the ratio of total debt over total assets is not significantly different between the two groups. Instead, the differences in capitalization seem to stem from a more intense use of informal sources of financing by managers of Italian origin. In the fourth and fifth columns of Table 3 we report the estimates from OLS regressions where the dependent variables are accounts payable over total assets, and a dummy variable (trade credit user) that takes a value of one if the firm uses trade credit-i.e. accounts payable are greater than zero-and zero otherwise. We find that firms led by managers of Italian origin resort significantly more to trade credit as a source of financing than companies run by managers of Germanic origin. This effect is economically significant: The ratio of trade credit to assets is on average 1.8 percentage points higher for firms where the manager is of Italian origin, explaining $9 \%$ of its total standard deviation.

In terms of the firms' asset structure, results in the third column show that the difference in cash holdings across firms run by managers of different cultural background disappears once we account for the effect of the included covariates. We therefore exclude cash holdings as a dependent variable in the following analysis. By contrast, we observe that firms led by managers of Italian origin are willing to lend more credit to their customers, as confirmed by the positive and significant effect of the Italian cultural dummy on the ratio of accounts receivable to total assets reported in the last column. This result is consistent with the larger use of trade credit among these firms found in the fourth column, and suggests that managers of Italian origin have a preference for this type of credit. The economic significance of the cultural dummy is of a similar order of magnitude for both usage and granting of trade credit. In the latter case, the cultural dummy explains $9.2 \%$ of the variation in the ratio of accounts receivable to total assets. $^{9}$

Overall, the findings in Table 3 document a positive and significant relation between the presence of a manager of Italian origin and the use of informal firm financing arrangements. In order to interpret these

\footnotetext{
${ }^{9}$ A potential concern with the results of Table 3 is that many of the control variables could be endogenous to the cultural origin of the firms. To mitigate this concern, in Appendix $\mathrm{C}$ we re-run the estimations of Table 3 only with controls for firm and CEO age. The results remain qualitatively unchanged. We also repeat the estimations using the cultural origin of the Board of Directors of the firms, i.e. a dummy equal to one when the majority of the members of the board have an Italian origin, in lieu of the cultural origin of the CEO. Given that the sample firms are privately held and most of them are small, there is usually no distinction between ownership and management. In fact, the results of these estimations, contained in Appendix D, are very similar to the ones in Table 3.
} 
results in terms of choice/preference of the top management for such forms of financing, we need to ensure that the estimated coefficients are not capturing a spurious correlation between the cultural origin of the manager and other unobserved factors. In the remainder of the paper, we discuss and rule out several alternative interpretations of our results.

\section{Controlling for Credit Supply}

One alternative interpretation of our results is that firms led by a manager of Italian cultural origin are somehow constrained and forced to turn to trade credit in substitution for more formal sources of debt (Biais and Gollier, 1997; Burkart and Ellingsen, 2004). In this respect, our specifications already control for firm-specific variables that are commonly associated with financial constraints, such as size, asset tangibility, and firm age (see e.g., Berger and Udell, 1995; Kaplan and Zingales, 1997; Hadlock and Pierce, 2010; Klapper et al., 2011; among many others). However, firms may be rationed in their access to external financing for reasons other than their financial health. This is the case, for example, when banks reduce lending due to liquidity or recapitalization constraints, as in the aftermath of the financial and European sovereign crises and with other shocks to the supply of credit (Khwaja and Mian, 2008; Jiménez et al., 2012). Additionally, firms' access to finance is reduced when bank competition is low (Love and Peria, 2015). In geographical areas with few bank branches, those banks may use their market power and apply stringent conditions on lending.

\subsection{Controlling for local credit supply}

As a first step to investigate this alternative explanation, we control for the credit supply at the municipality level. In Table 4, we augment our basic specifications with the yearly aggregate logarithmic growth in bank loans in the municipality where the firm is headquartered. The data come from the statistical database of the Bank of Italy. ${ }^{10}$ We do not have access to bank-firm data so we cannot directly identify which banks lend to our sample firms. However, we believe that the loan growth at the municipality level represents a good indicator of the availability and the ease of access of bank credit in the area where the company is located. Table 4 reports the OLS estimates from the specifications with the additional control variable; it has a smaller sample size because the dataset of the Bank of Italy reports aggregate bank loans for municipalities with at least three branches, and some of our sample

\footnotetext{
${ }^{10} \mathrm{http} / / /$ www.bancaditalia.it/statistiche/basi-dati/bds/index.html
} 
firms are headquartered in municipalities with a smaller number of branches. ${ }^{11}$ The main results of Table 3 are qualitatively unchanged after controlling for loan supply.

\subsection{Controlling for a credit supply shock: The financial crisis}

We next explore whether our results could be driven by a lower supply of credit to firms led by a manager of Italian cultural origin by exploiting a unique feature of the firms in our sample, namely, that all of them are privately held, and the majority of them are small firms. Thus, the management of our sample firms is likely to be stable over a short time horizon. We take advantage of this feature to overcome the limitation of the Orbis data on firm managers (which refer to the last available balance sheet date), and exploit the panel dimension of the financial statement data, by assuming that the cultural origin of the management of our companies is stable throughout the sample years. Balance sheet data on the sample firms are available on Orbis for the most recent ten years.

Looking at the entire ten-year panel enables us to address an additional critique to our findings, i.e. that our results may be driven by the differential impact of the financial and sovereign crisis on firms led by managers of different cultural origins. If for some unobserved reasons (such as flight-to-quality, higher riskiness, lower liquidity of the lending banks, etc.), firms led by a manager of Italian cultural origin were unable to secure credit from banks during the crisis, then the greater use of trade credit could simply be the result of these firms substituting for the unavailable institutional credit during this period. Moreover, existing studies have linked the manager's cultural origin with firm performance under competitive pressure (Nguyen et al., 2017). Our findings could then be consistent with a scenario where firms run by a manager of any cultural origin adopt similar policies in normal times, but managers of Italian culture did not react as well as managers of Germanic culture to the challenges imposed by the crisis. As a result, firms run by the former could be more constrained and forced to resort to informal sources of funding.

To assess whether this is the case, we re-estimate our baseline OLS specifications on the panel dataset of firms headquartered in the province, and evaluate whether the results observed in the cross-sectional dataset stem from the crisis period. For this purpose, we add the interaction between our indicator for CEO of Italian origin and a dummy variable Crisis, which takes a value of one if the year of the financial statement coincides with the period of credit tightening in the South Tyrol province. The statistics on

\footnotetext{
${ }^{11}$ To overcome this problem, in untabulated results available upon request, we control for credit supply by including the number of bank branches operating in the firm municipality. The results are very similar to those reported in Table 4.
} 
conditions of credit supply provided by the Bank of Italy (2007-2016) indicate that there was a credit contraction and a tightening in credit conditions in the province during years 2008-2013, and that such contraction relaxed from year 2014 onwards. ${ }^{12}$ Therefore, we define two dummy variables accordingly: Crisis, which equals one for 2008-2013 and zero otherwise, and Post Crisis which equals one for the years 2014-2015 and zero otherwise. We interact each of these two dummies with our cultural origin dummy.

We present the results in Table 5, panels A and B. In panel A, we include industry and year fixed effects; the latter subsume the effect of the un-interacted Crisis and Post Crisis dummies. In panel B, we further control for time-unvarying unobserved heterogeneity at the firm level, by including firm fixed effects. The fixed effects in panel B subsume the effect of the un-interacted cultural origin dummy, but the interaction term provides us with a direct test for a differential behavior of firms led by a manager of Italian cultural origin relative to firms led by a manager of Germanic cultural origin during the crisis. In both panels, we account for the fact that observations of a same firm over time are not independent, and cluster the standard errors at the firm level.

The estimated coefficients for the dummy of Italian cultural origin in panel A of Table 5 largely confirm that firms led by managers of Italian origin are characterized by a larger recourse to informal sources of funding than firms run by managers of Germanic origin. Indeed, the coefficients of the un-interacted cultural origin dummy are positive and statistically significant in the last three columns, and have approximately the same magnitude as the coefficients in Table 3 . These results suggest that the higher recourse to trade credit among firms managed by a manager of Italian cultural origin existed before the crisis, confirming our interpretation of the results as driven by preferences for informal credit among managers of this cultural group.

Furthermore, the coefficients of the interaction term with the Crisis dummy are inconsistent with the idea that firms led by a manager of Italian cultural origin were more constrained during the crisis and hence forced to obtain more trade credit to compensate for the lack of bank credit. On the one hand, the coefficients of this interaction term for the trade credit ratios (third and last columns in panel A) are small and statistically insignificant, suggesting that on average, firms led by managers of Italian origin were not more likely to resort to trade credit in the intensive margin during the crisis. Additionally, the coefficient of the interaction term of the crisis with the debt to assets ratio is positive and significant for

\footnotetext{
12 This period contrasts with the crisis period in Italy, which started in 2008 and continued until at least the end of our sample period. However, the South Tyrol province developed differently to the rest of Italy. In fact, it is the only Italian province that had a higher GDP level in 2015 than in 2007. Our results are qualitatively equal if we define a single Crisis dummy taking the value one from 2008 to 2015, coinciding with the crisis in Italy.
} 
the specification for debt to total assets, suggesting that firms led by a manager of Italian cultural origin increased their access to formal sources of credit during the crisis. The regressions in panel B of Table 5, which include firm fixed effects, further confirm this interpretation, by showing that, during the crisis, these firms obtained more credit from formal institutions (second column) and increased the provision of trade credit to their clients (last column). In line with the redistribution theory of trade credit, this result suggests that firms that have access to formal sources of credit are able to provide liquidity to their clients in times when bank credit is scarce (Garcia-Appendini and Montoriol-Garriga, 2013). Overall, these results suggest, if anything, that firms led by a manager of Italian cultural origin were less constrained than their Germanic-led counterparts, and do not support the idea that our main results are driven by a lack of access to formal credit by those firms.

In addition, the fourth column in both panels of Table 5 shows that during the financial crisis, firms led by managers of Italian origin were more likely to use trade credit in the extensive margin, compared to the firms led by managers of Germanic origin. This can be seen by the positive and statistically significant coefficient for the cultural origin variable when the dependent variable is the use of trade credit. This however did not translate in a use of larger amounts of trade credit in the intensive margin, as shown above. Collectively, the results in Table 5 suggest that firms led by a manager of Italian cultural origin are more likely to tap on this informal source of credit to obtain small amounts of credit and continue their operations, not because they are constrained, but because they have an easier access to this form of financing given that it is common practice within their cultural group.

Overall, the findings in this section show that our main results are robust to controlling for the local and temporary availability of bank credit. In the following sections, we will further explore whether our main result could be capturing other unobserved relationships between the cultural origin of the firms and the firms' financing outcomes, and not truly reflecting the preference for credit from their informal network of suppliers.

\section{Robustness Checks}

In this section we address additional potential endogeneity concerns that may bias our analysis, in terms of both reverse causality and omitted variables. We also investigate if our main result carries through with other forms of finance than trade credit. Reverse causality or self-selection occurs if managers of a given cultural origin choose to work for firms with given characteristics. In our setting, this would be the case if managers of Italian (Germanic) origin were attracted by companies with higher (lower) recourse to informal sources of financing. An omitted variable bias arises in the presence of additional factors that affect both the financing decisions of firms and the cultural origin of managers. We adopt 
three approaches to control for endogeneity issues: Subsample analysis, a matching approach, and an instrumental variables estimation.

\subsection{Subsample analysis}

We address reverse causality concerns by replicating the results of Table 3 over subsamples of firms where self-selection is unlikely to occur. First, we restrict our analysis to the subsample of family firms where the manager is a family member. Such companies are typically founded and run by the same family over their entire life. This minimizes the possibility that managers of a given cultural origin choose to work for firms with certain characteristics. We retrieve information on the ownership structure of the sample firms from Orbis, and we classify a company as a family firm if one or several related individuals hold the majority of the shares. We then restrict our sample to those family firms whose manager is a family member, i.e. he/she is one of the majority shareholders or carries the surname of the controlling family. ${ }^{13}$ Around 55\% of the original sample firms satisfy the restrictions. Around $28 \%$ of these firms are led by a family of Italian cultural origin.

We re-estimate our main specification over the subsample of family firms, and report the estimates in panel A of Table 6. For the benefit of space, we only report the coefficients for the cultural origin dummy; however, the estimations in this table include all the controls of Table 3. The positive and significant coefficient of the $C E O$ of Italian origin dummy for the regressions explaining trade credit variables confirms that the more intense recourse to informal financing is a general feature of these firms and is not caused by endogeneity. In terms of magnitude, the coefficients are only slightly larger than the ones in Table 3.

Second, we control for a potential endogenous matching of cultural origin of the manager and firm size. To the extent that firms where the manager is of Germanic origin are, overall, larger and better established than their Italian counterparts (see Table 2), our results could be capturing different financing policies driven by firm size. While we control for firm size in all our specifications, the effect may be non-linear. To overcome this issue, we perform the estimations over the more homogeneous subsample of micro firms, defined as firms with total assets up to $2 \mathrm{~m}$ euros. Results over the subsample of micro firms are presented in panel B of Table 6. They consistently show that firms where the manager is of

\footnotetext{
${ }^{13}$ Our method may, in fact, underestimate the number of family firms in the sample as, following Italian law, women in South Tyrol retain their maiden name after marriage. This, however, is unlikely to introduce any bias in the analysis, as it is expected to affect family firms where the CEO is of either Italian or Germanic origin in the same way.
} 
Italian origin are less capitalized, have a preference for informal trade credit, and extend more credit to their clients. Once again, the coefficients are of similar magnitude as the ones found in Table 3.

Third, we address the possibility that managers of a given cultural group are concentrated in certain industry sectors. Figure 2 displays the distribution of the managers' cultural origin by industry. We note that, with few exceptions, Italian- and Germanic-led companies are represented relatively similarly in the various industries. The three business sectors that have the most unequal representation between the two cultures are energy (electricity, gas, steam, and air conditioning supply), manufacturing, and construction. While energy and manufacturing have the relatively highest concentration of companies led by a manager of Germanic origin, this situation is reversed for the construction sector. To ensure that our results cannot be explained away by these differences, we re-run our main regression on the subsample of firms that excludes the construction, manufacturing, and energy sectors. Estimates are reported in panel $\mathrm{C}$ of Table 6, and they mirror our main results, with somewhat larger estimated coefficients for the trade credit variables than the corresponding ones of Table 3.

Fourth, we control for the possibility that our results are driven by an omitted variable, namely, the terms of credit given by the firms' trading partners. The trade credit literature suggests that the terms of credit are largely invariant within an industry, and related to the nature of the traded good ( $\mathrm{Ng}$ et al., 1999; Giannetti et al., 2011). Given that our estimations contain industry fixed effects, the coefficients obtained so far are unlikely to be biased due to differences across industries in the terms of trade credit. However, terms of trade differ within the euro area (ECB, 2011) and, hence, may be different for imported purchases compared to domestic purchases. Given the location of the South Tyrol area on the border with Austria and Switzerland, one potential concern is that firms with a manager of Germanic origin may be more likely to buy goods from these German-speaking countries, and that the observed differences are due to the different credit terms in these countries. Therefore, we need to ensure that our results cannot be mechanical explained by different trading patterns between the two cultures.

Unfortunately, Orbis does not disclose the amount of firms' imports. Thus, to control for this potential bias, we re-run our estimation over a subsample of firms that are less likely to be importers. The most import-intense sectors in South Tyrol are the manufacturing, and the wholesale and retail trade sectors, which account for about $95 \%$ of the province imports. ${ }^{14}$ Therefore, in panel D of Table 6 we re-run our main regressions while excluding these two sectors. The significant coefficient estimates for the indicator of cultural origin confirm that firms led by managers of Italian origin are characterized by a larger recourse to informal financing than firms run by managers from the Germanic culture.

\footnotetext{
${ }^{14}$ This information was kindly provided to us by ISTAT and ASTAT.
} 


\subsection{Matching}

From the above subsample analysis, we conclude that the more intense recourse to informal financing is a general feature of firms led by managers of Italian cultural origin, and that it is not consistent with endogenous matching. In this section, we take this analysis one step further and compare the financing choices of Italian-led firms with their closest counterfactual led by a manager of Germanic cultural origin. That is, for each firm led by a manager of Italian origin, we find a set of Germanic-led firms with similar observable characteristics that may confound the relationship between cultural origin and financing outcome variables. We then perform a regression analysis using the subset of closest matches. Such a matching exercise should help to better identify the effect of the cultural origin of the manager on the firms' financing choices.

Following the discussion in the previous section, we first match firms in terms of size and industry sector, to control for differences in access to formal sources of credit, as well as for different terms of trade credit and selection of firms into certain sectors based on the cultural origin of the CEO. Specifically, we restrict the analysis to the set of firms with a manager of Italian origin for which there are at least two firms led by managers of Germanic origin in the same industry and size group (micro, small, medium, or large firms), and we re-run the regressions in Table 3 among the resulting subsample of comparable firms. Results from these estimations can be found in Table 7, panel A. The estimates are qualitatively very similar to the estimates in Table 3, suggesting that our results are not driven by a selection of firms led by a manager of Italian cultural origin into particular industries or size groups where the use of informal vs formal sources of financing may differ.

Given our unique setting where firms run by managers from either the Italian or the Germanic culture are headquartered in the same province, geographical considerations should be a second order concern. ${ }^{15}$ Nevertheless, as a result of the Italianization of South Tyrol, Italian entrepreneurs who moved to the province ended up being geographically concentrated in few municipalities and specialized in certain industry sectors (Steininger, 2003). While the specialization by sector of economic activity disappeared following the 1972 agreement - and has been taken care of by matching on the industry sector - the concentration of Italians and firms led by a manager of Italian cultural origin in the valleys that are easily accessible from the rest of Italy survives essentially unchanged to this day. If firms led by a manager of Italian cultural origin are located in the valleys with easier access to services and infrastructures while firms led by managers of Germanic origin are predominantly headquartered in mountain villages, then

\footnotetext{
${ }^{15}$ See Degryse and Ongena (2005) and Agarwal and Hauswald (2010) for studies on how geographic proximity to financial institutions affects financial decisions.
} 
failing to match by the location of the firms may bias our findings due to omitted variables linked to firm location. To address this concern, we refine the match by size and industry by adding a third dimension and restricting the sample to firms that are headquartered in the same administrative district ("circoscrizione"; there are eight districts in the South Tyrol province). Results of this matching exercise are found in Table 7, panel B. Once again, the results mirror our previous findings, suggesting that they are robust to a potential clustering of firms led by a manager of Italian cultural origin into specific locations..$^{16}$

\subsection{Instrumental variables}

Our last approach to address endogeneity concerns is to use the proportion of the Italian-speaking population in the municipality where the firm is located as an instrument for the cultural origin of the manager. ${ }^{17}$ Our choice of instrument follows a well-established praxis of using measures of the local availability of the characteristic of interest, which in our context is cultural origin. As such, our approach is very similar to that of Berger et al. (2005) who instrument an individual bank's size with the median size of banks in the local market, and to Bottazzi et al. (2008) who in a cross-country study instrument the fraction of how many partners have prior business experience in a venture capital firms with the fraction of deals made by a venture capital firm that has at least one partner with prior business experience in each country. In support to the relevance condition, we find that the first-stage regression of the Italian-origin manager dummy on the instrumental variable and all the included instruments yields a highly significant coefficient of 0.582 with a standard error of 0.022 , and the first-stage $F$-statistic is 33.89. Results are contained in Table 8. Thus, the fraction of Italian speakers in the municipality is a good predictor of the cultural origin of the managers of the firms located in that municipality.

Our main identification assumption is that the proportion of Italian speakers in the municipality of the firm's headquarters is uncorrelated with a given firm's financing decisions. The "Italianization" of the South Tyrol area guarantees that this exclusion restriction holds. In fact, Italian immigrants concentrated

\footnotetext{
${ }^{16}$ For robustness, in Appendix E we repeat the estimations of the panel over a subsample of family firms where the CEO is a family member and that are headquartered in the bilingual city of Bolzano. The advantage of this specification is that (i) family firms are typically founded and run by the same family over their entire life so the cultural origin of the management is more likely to be stable, and (ii) we can further control for differences in access to credit by focusing on a single city, the province's largest, in which several bank types are present and hence the local supply of credit is less constrained. Results in this analysis are consistent with the previous ones.

${ }^{17}$ We obtain data on the proportion of Italian speakers in each of the 60 municipalities in South Tyrol as of year 2011 from ASTAT (2015).
} 
mostly in the cities of Merano and Bolzano and the easily accessible valleys, while the more secluded mountain areas remained predominantly Germanic. Thus, the proportion of Italians in each municipality has been mainly driven by historical and geographical reasons (Peterlini, 2009), and as such it should be orthogonal to the way firms finance themselves or structure their assets. Under this crucial condition, the instrument allows us to isolate the portion of the variation in the cultural origin of the firm's manager that is exogenous to the financing structure, and hence to better identify the causal link between cultural origin and financing structure.

Table 9 replicates the estimations of Table 3, by instrumenting the cultural origin of the manager with the fraction of Italian speakers in the municipality. The coefficients are thus the second-stage estimates of regressions of each outcome variable on the predicted values of the cultural origin. The results so obtained largely confirm the findings estimated with OLS: Companies run by managers from the Italian culture are less capitalized and make a greater use of informal trade credit than companies managed by CEOs from the Germanic culture. The economic and statistical significance of the IV estimates are larger than the OLS counterparts, suggesting that the OLS coefficients are a conservative estimate of the exogenous component of the effect of culture on the financing structure. ${ }^{18}$

\subsection{Other forms of financing}

In light of our results and robustness checks, we interpret our findings as supportive of the preference expressed by managers of Italian culture for higher recourse to debt in general, and to informal sources of debt in particular. Consistently with this interpretation, one would also expect retained earnings to be lower and the use of other sources of informal financing to be larger in Italian-led firms than in Germanic-led firms. To investigate this point, we select a subsample of firms that provide information in their balance sheet (obtained from Aida-Bureau van Dijk) on retained earnings and shareholders' loans. Shareholders' loans are a form of financing provided by shareholders, which is widely used by

\footnotetext{
${ }^{18}$ In fact, the IV estimates estimate a local average treatment effect (LATE), which is the average treatment effect among the "compliers", i.e. subpopulations that are induced by the instrument to change the value of the endogenous cultural origin. In our setup, the proportion of Italian speakers in a municipality is likely to have a larger effect on the cultural origin of the CEOs among industries where Italian and Germanic management is closer to the population distribution. The descriptive statistics in Table 1 show that the distribution of firms among Germanic and Italian cultural origin closely mirrors the population distribution. However, there are some industries where there is greater prevalence of one cultural group over the other. In fact, the coefficients found for the subsample of industries in which the distribution into Italian and Germanic cultural origin is more homogeneous (Table 6, panel C), are closer to the IV estimations found in this section.
} 
small and medium sized firms in Italy for tax purposes and is classified as debt. Given their nature, shareholders' loans belong to the category of informal financing. We regress retained earnings over total assets as well as shareholders' loans over total assets on our set of control variables and present the findings in Table 10. In line with our predictions, we document significantly lower retained earnings in firms led by managers of Italian cultural origin. Those firms also show a higher proportion of shareholders' loans, although the coefficient is not statically significant, possibly due to the reduced sample size.

\section{Overall Conclusions}

This paper examines the relation between the cultural origin of firm managers and corporate financing behavior. Motivated by the evidence from previous literature on individuals' preferences for conducting economic activities within either formal institutions or informal networks, and the literature on managerial style, we conjecture that the composition of a firm's liabilities can be shaped by culturally embedded preferences of their managers. Consistent with our conjecture, we find large and significant differences in the financing structure of individuals of different cultural origin. Our method, which analyzes firms within a small geographical province within one country, ensures that these results are not driven by institutional, regulation, religious or economic differences associated with the different cultures. Through a series of robustness checks, we further rule out that our results are driven by omitted variables and other endogeneity concerns. Our results are consistent with the existence of culturally embedded preferences for different types of financing structures.

For the benefit of internal validity and identification, we have set up our analysis in one particular province in Italy which hosts two different cultural groups. However, we believe that our results have, in general, a much wider external validity. In particular, the South Tyrol province has a level of GDP comparable to that of many advanced economies, and aligned with the average GDP of the European Union. Moreover, its residents are active in a wide range of sectors, from agriculture to manufacturing and services, and enjoy a high degree of industrialization. Thus, we believe that our results are informative on the effect of culture on the financing practices of firms in wider setups, particularly for advanced economies.

Our main results highlight culture as one of the drivers of the variation in the recourse to informal finance in a multi-cultural setup. In terms of policy implications, our results suggest that one-size-fits-all regulations aimed at incentivizing the access to formal sources of finance could have heterogeneous effects depending on the preferences of different cultural groups affected by the regulation. Similarly, our study suggests that financial education should be structured differently according to the preferences of the different target cultural groups. 


\section{References}

Agarwal, S. and R. Hauswald, 2010. Distance and Private Information in Lending. Review of Financial Studies 23, 1-32.

Angerer, S. D. Glätzle-Rützler, P. Lergetporer and M. Sutter, 2016. Cooperation and discrimination within and across language borders: Evidence from children in a bilingual city, European Economic Review 90, 254-264.

ASTAT, 2015, "Statistisches Jahrbuch für Südtirol 2014/Annuario statistico della Provincia di Bolzano 2014”. Table 3.18, p. 118. Autonome Provinz Bozen, Südtirol Landesinstitut für Statistik / Provincia Autonoma di Bolzano, Alto Adige, Istituto provinciale di statistica.

Bank of Italy, 2007-2016. L'economia delle Provincie autonome di Trento e di Bolzano, Economie Regionali, Filiali di Trento e Bolzano.

Bandiera, O., Guiso, L., Prat, A. and R. Sadun, 2010. Italian managers: Fidelity or performance. In: Boeri, T (Ed.) The ruling class: Management and politics in modern Italy, Oxford University Press, p. 105-202.

Becker, S.O., Boeckh, K., Hainz, C. and L. Woessmann, 2016. The Empire Is Dead, Long Live the Empire! Long-Run Persistence of Trust and Corruption in the Bureaucracy. Economic Journal 126, 4074.

Benvenuto, O., 2007. "South Tyrol in Figures 2008”. Table 11, p. 19. Provincial Statistics Institute of the Autonomous Province of South Tyrol, Bozen/Bolzano.

Berger, A., Miller, N., Petersen, M., Rajan, R., Stein, J., 2005. Does function follow organizational form? Evidence from the lending practices of large and small banks. Journal of Financial Economics 76, 237-269.

Berger, A.N. and G.F. Udell, 1995. Relationship Lending and Lines of Credit in Small Firm Finance. The Journal of Business 68, 351-381.

Bertrand, M. and A. Schoar, 2003. Managing with Style: The Effect of Managers on Firm Policies, The Quarterly Journal of Economics 118, 1169-1208.

Biais, B., and C. Gollier, 1997. Trade credit and credit rationing. Review of Financial Studies 10, $903-$ 937.

Bottazzi, L., M. Da Rin, and T. Hellmann, 2008. Who are the active investors? Evidence from venture capital. Journal of Financial Economics 89, 488-512. 
Brick, I. and W. K. H. Fung, 1984. Taxes and the theory of trade debt," Journal of Finance 39, 11691176.

Burkart, M. and T. Ellingsen, 2004. In-Kind Finance: A theory of trade credit, American Economic Review 94, 569-590.

Chen, K., 2013. The Effect of Language on Economic Behavior: Evidence from Savings Rates, Health Behaviors, and Retirement Assets. American Economic Review 103, 690-731.

Chui, A., A. Lloyd and C. Kwok, 2002. The Determination of Capital Structure: Is National Culture a Missing Piece to the Puzzle?, Journal of International Business Studies 33, 99-127.

Cuñat, V., 2007. Trade Credit: Suppliers as Debt Collectors and Insurance Providers, Review of Financial Studies 20, 491-527.

Daripa, A. and Nilsen, J., 2011. Ensuring sales: A theory of inter-firm credit. American Economic Journal: Microeconomics 3, 245-279.

Degryse, H. and S. Ongena, 2005. Distance, Lending Relationships, and Competition. Journal of Finance 60, 231-266.

Delis, M., C. Gaganis, I. Hasan, and F. Pasiouras, 2017. The Effect of Board Directors from Countries with Different Genetic Diversity Levels on Corporate Performance. Management Science 63, 231-249.

ECB, 2011. Monetary and financial developments. Monthly Bulletin April, European Central Bank, Frankfurt.

El Ghoul, S. and X. Zheng, 2016. Trade credit provision and national culture, Journal of Corporate Finance 41, 475-501.

Emery, Gary W., 1984. A Pure Financial Explanation for Trade Credit, Journal of Financial and Quantitative Analysis 19, 271-285.

Fernández, R., 2011. Does culture matter? in, J. Benhabib, M. O. Jackson and A. Bisin, editors, Handbook of Social Economics, Vol. 1A, North-Holland.

Ferris, S., 1981. A Transactions Theory of Trade Credit Use, Quarterly Journal of Economics 96, 243270.

Frijns, B., O. Dodd, and H. Cimerova, 2016. The impact of cultural diversity in corporate boards on firm performance. Journal of Corporate Finance 41, 521-541. 
Garcia-Appendini, E. and J. Montoriol-Garriga, 2013. Firms as liquidity providers: Evidence from the 2007-2008 financial crisis. Journal of Financial Economics 109, 272-291.

Giannetti, M., 2003. Do Better Institutions Mitigate Agency Problems? Evidence from Corporate Finance Choices. Journal of Financial and Quantitative Analysis 38, 185-212.

Giannetti, M., Burkart, M. and Ellingsen, T., 2011. What you sell is what you lend? Explaining trade credit contracts. Review of Financial Studies, 24(4), pp.1261-1298.

Griffin, D., O. Guedhami, C.C.Y. Kwok, K. Li, and L. Shao, 2017. National culture: The missing country-level determinant of corporate governance. Journal of International Business Studies, forthcoming.

Grinblatt, M., and M. Keloharju, 2001. What makes investors trade? Journal of Finance 56, 589-616.

Guiso, L., P. Sapienza, and L. Zingales, 2004. The Role of Social Capital in Financial Development. American Economic Review 94, 526-556.

Guiso, L., P. Sapienza, and L. Zingales, 2006. Does Culture Affect Economic Outcomes? Journal of Economic Perspectives 20, 23-48.

Hadlock, C.J. and J.R. Pierce, 2010. New evidence on measuring financial constraints: Moving beyond the KZ index. Review of Financial Studies 23, 1909-1940.

Jiménez, G., Ongena, S., Peydró, J-L., and J. Saurina, 2012. Credit Supply and Monetary Policy: Identifying the Bank Balance-Sheet Channel with Loan Applications, American Economic Review 102, 2301-2326.

Kaplan, S.N. and L. Zingales, 1997. Do investment-cash flow sensitivities provide useful measures of financing constraints? Quarterly Journal of Economics 112, 169-215.

Karolyi, G.A., 2016. The gravity of culture for finance, Journal of Corporate Finance 41, 610-625.

Khwaja, A., and A. Mian, 2008. Tracing the Impact of Bank Liquidity Shocks: Evidence from an Emerging Market, American Economic Review 98, 1413-1442.

Klapper, L., Laeven, L. and R. Rajan, 2011. Trade credit contracts. Review of Financial Studies 25, 838867.

Lee, Y. and J. Stowe, 1993. Product risk, asymmetric information, and trade credit, Journal of Financial and Quantitative Analysis 28, 285-300. 
Levine, R., C. Lin and W. Xie, 2016. Corporate Resilience to Banking Crises: The Roles of Trust and Trade Credit, Journal of Financial and Quantitative Analysis, forthcoming.

Li, K., Griffin, D., Yue, H. and L. Zhao, 2015. How does culture influence corporate risk-taking? Journal of Corporate Finance 23, 1-22.

Love, I. and M. S. M. Pería, 2015. How Bank Competition Affects Firms' Access to Finance, World Bank Economic Review 29, 413-448.

Ng, C.K., J.K. Smith and R.L. Smith, 1999. Evidence on the Determinants of Credit Terms Used in Interfirm Trade, Journal of Finance 54, 1109-1129.

Nguyen, D.D., J. Hagendorff, and A. Eshraghi, 2017. Does CEO Cultural Heritage Affect Performance under Competitive Pressure? Review of Financial Studies, forthcoming.

Pan, Y. Siegel, S. and T.Y. Wang, 2016. Corporate Risk Culture, Journal of Financial and Quantitative Analysis, forthcoming.

Peterlini, O., 2009. The South-Tyrol Autonomy in Italy, Historical, Political and Legal Aspects. In: Oliveira J./Cardinal P. (Eds.) (2009): One Country, Two Systems, Three Legal Orders - Perspectives of Evolution, Springer.

Petersen, M.A. and R.G. Rajan, 1997. Trade Credit: Theories and Evidence. Review of Financial Studies $10,661-691$.

Puntscher, S., Hauser, C., Pichler, K. and G. Tappeiner, 2014. Social Capital and Collective Memory: A Complex Relationship. Kyklos 67, 116-132.

Smith, J.K., 1987. Trade Credit and Informational Asymmetry. Journal of Finance 42, 863-872.

Steininger, R., 2003. South Tyrol: A Minority Conflict of the Twentieth Century. Transaction Publishers, New Brunswick, USA; London, UK.

Sutter, M., S. Angerer, D. Glätzle-Rützler, and P. Lergetporer, 2015. The effects of language on children's intertemporal choices. IZA Discussion Paper No. 9383. 


\section{Table 1. Summary statistics}

This table reports OLS estimates for the cross section of sample firms headquartered in the South Tyrol province with a CEO of Italian or Germanic origin as of the latest available year prior to 2016. The origin of the CEO is determined as illustrated in Appendix A. Dependent and control variables are computed as explained in Appendix B.

\begin{tabular}{lcccccc}
\hline Variables & $\mathrm{N}$ & Mean & Std & $\mathrm{p} 25$ & $\mathrm{p} 50$ & $\mathrm{p} 75$ \\
\hline CEO cultural origin: & & & & & & \\
CEO of Italian origin & 4,003 & 0.294 & 0.456 & 0 & 0 & 1 \\
& & & & & & \\
Dependent variables: & & & & & & \\
Total liabilities / Total assets & 4,003 & 0.730 & 0.326 & 0.531 & 0.783 & 0.935 \\
Total debt / Total assets & 4,003 & 0.173 & 0.250 & 0 & 0.001 & 0.309 \\
Cash / Total assets & 3,857 & 0.104 & 0.159 & 0.004 & 0.031 & 0.138 \\
Accounts Payable / Total assets & 4,003 & 0.147 & 0.200 & 0 & 0.063 & 0.215 \\
Accounts Receivable / Total assets & 4,003 & 0.187 & 0.239 & 0 & 0.070 & 0.314 \\
& & & & & & \\
Firm control variables: & & & & & & \\
Firm size & 4,003 & 13.869 & 1.804 & 12.702 & 13.919 & 15.056 \\
Asset tangibility & 4,003 & 0.297 & 0.310 & 0.033 & 0.158 & 0.537 \\
Sales growth & 4,003 & 0.033 & 0.600 & -0.127 & 0.010 & 0.143 \\
Investment & 4,003 & 0.038 & 0.083 & 0.003 & 0.015 & 0.044 \\
Operating margin & 4,003 & 0.277 & 1.010 & 0.030 & 0.086 & 0.234 \\
Firm age & 4,003 & 15.350 & 14.635 & 5 & 11 & 22 \\
& & & & & & \\
CEO control variables: & & & & & & \\
CEO age & 4,003 & 52.554 & 11.435 & 45 & 52 & 60 \\
CEO is male & 4,003 & 0.886 & 0.317 & 1 & 1 & 1 \\
\hline
\end{tabular}




\section{Table 2. T-tests for differences in mean values}

This table reports mean values, standard deviations and t-tests of differences in means (with associated p-values) of dependent and control variables for the cross section of sample firms headquartered in the South Tyrol province with a CEO of Italian or Germanic origin as of the latest available year prior to 2016. Firm controls refer to the last available balance sheet date in Orbis (as of March 2016). The origin of the CEO is determined as illustrated in Appendix A. Dependent and control variables are computed as explained in Appendix B.

\begin{tabular}{lcccccc}
\hline & \multicolumn{2}{c}{ CEO of Italian origin } & \multicolumn{2}{c}{ CEO of Germanic origin } & & \\
Variables & Mean & Std & Mean & Std & t-test & p-value \\
\hline Dependent variables: & & & & & & \\
Total liabilities / Total assets & 0.760 & 0.336 & 0.715 & 0.322 & 3.890 & 0.000 \\
Total debt / Total assets & 0.154 & 0.221 & 0.176 & 0.255 & -2.652 & 0.008 \\
Cash / Total assets & 0.118 & 0.174 & 0.098 & 0.152 & 3.386 & 0.001 \\
Accounts Payable / Total assets & 0.170 & 0.217 & 0.139 & 0.193 & 4.259 & 0.000 \\
Accounts Receivable / Total assets & 0.214 & 0.256 & 0.176 & 0.229 & 4.326 & 0.000 \\
& & & & & & \\
Firm control variables: & & & & & & \\
Firm size & 13.439 & 1.955 & 14.079 & 1.706 & -9.649 & 0.000 \\
Asset tangibility & 0.244 & 0.288 & 0.314 & 0.313 & -6.760 & 0.000 \\
Sales growth & 0.001 & 0.661 & 0.039 & 0.561 & -1.703 & 0.089 \\
Investment & 0.037 & 0.082 & 0.038 & 0.083 & -0.470 & 0.639 \\
Operating margin & 0.234 & 1.081 & 0.295 & 0.985 & -1.629 & 0.104 \\
Firm age & 14.107 & 12.678 & 16.025 & 15.347 & -4.025 & 0.000 \\
& & & & & & \\
CEO control variables: & & & & & & \\
CEO age & 53.535 & 12.188 & 52.263 & 11.112 & 3.041 & 0.002 \\
CEO is male & 0.848 & 0.360 & 0.900 & 0.300 & -4.371 & 0.000 \\
\hline
\end{tabular}




\section{Table 3. Cultural origin OLS regressions}

This table reports OLS estimates for the cross section of sample firms headquartered in the South Tyrol province with a CEO of Italian or Germanic origin as of the latest available year prior to 2016. The origin of the CEO is determined as illustrated in Appendix A. Dependent and control variables are computed as explained in Appendix B. Standard errors are corrected for heteroskedasticity. $* * *, * *$ and $*$ indicate statistical significance at the $1 \%, 5 \%$ and $10 \%$ levels, respectively.

\begin{tabular}{|c|c|c|c|c|c|c|}
\hline & $\begin{array}{c}\text { Total liabilities / } \\
\text { Total assets }\end{array}$ & $\begin{array}{l}\text { Total debt / } \\
\text { Total assets }\end{array}$ & $\begin{array}{c}\text { Cash / } \\
\text { Total assets }\end{array}$ & $\begin{array}{c}\text { Accounts payable / } \\
\text { Total assets }\end{array}$ & Trade credit user & $\begin{array}{c}\text { Accounts receivable } / \\
\text { Total assets }\end{array}$ \\
\hline \multirow[t]{2}{*}{ CEO of Italian origin } & $0.029 * *$ & 0.007 & 0.000 & $0.018 * *$ & $0.053 * * *$ & $0.016 * *$ \\
\hline & $(0.011)$ & $(0.008)$ & $(0.006)$ & $(0.007)$ & $(0.015)$ & $(0.008)$ \\
\hline \multirow[t]{2}{*}{ Firm size } & -0.005 & $0.020 * * *$ & $-0.022 * * *$ & 0.001 & $0.051 * * *$ & $0.006 * *$ \\
\hline & $(0.004)$ & $(0.002)$ & $(0.002)$ & $(0.002)$ & $(0.004)$ & $(0.002)$ \\
\hline \multirow[t]{2}{*}{ Asset tangibility } & -0.016 & $0.218 * * *$ & $-0.114 * * *$ & $-0.147 * * *$ & -0.037 & $-0.235 * * *$ \\
\hline & $(0.019)$ & $(0.016)$ & $(0.008)$ & $(0.011)$ & $(0.027)$ & $(0.011)$ \\
\hline \multirow{2}{*}{ Sales growth } & 0.009 & -0.003 & $0.007 *$ & 0.008 & 0.013 & $0.018 * * *$ \\
\hline & $(0.008)$ & $(0.007)$ & $(0.004)$ & $(0.006)$ & $(0.012)$ & $(0.006)$ \\
\hline \multirow[t]{2}{*}{ Investment } & -0.063 & $0.197 * * *$ & $-0.119 * * *$ & -0.019 & 0.062 & $-0.194 * * *$ \\
\hline & $(0.073)$ & $(0.051)$ & $(0.024)$ & $(0.041)$ & $(0.085)$ & $(0.033)$ \\
\hline \multirow[t]{2}{*}{ Operating margin } & $-0.012 * *$ & $-0.014 * *$ & $0.011 * * *$ & $-0.015^{* * *}$ & -0.011 & -0.001 \\
\hline & $(0.006)$ & $(0.005)$ & $(0.002)$ & $(0.003)$ & $(0.008)$ & $(0.002)$ \\
\hline \multirow[t]{2}{*}{ Firm age } & $-0.005 * * *$ & $-0.002 * * *$ & $0.001 * * *$ & $-0.001 * * *$ & $-0.002 * * *$ & -0.000 \\
\hline & $(0.000)$ & $(0.000)$ & $(0.000)$ & $(0.000)$ & $(0.001)$ & $(0.000)$ \\
\hline \multirow[t]{2}{*}{ CEO age } & 0.003 & 0.002 & 0.000 & 0.003 & $0.008 *$ & $0.005 * *$ \\
\hline & $(0.003)$ & $(0.002)$ & $(0.001)$ & $(0.002)$ & $(0.004)$ & $(0.002)$ \\
\hline \multirow[t]{2}{*}{ CEO age squared } & -0.000 & -0.000 & -0.000 & -0.000 & -0.000 & $-0.000 * *$ \\
\hline & $(0.000)$ & $(0.000)$ & $(0.000)$ & $(0.000)$ & $(0.000)$ & $(0.000)$ \\
\hline \multirow[t]{2}{*}{ CEO is male } & -0.009 & 0.015 & 0.007 & $-0.020^{*}$ & 0.011 & -0.009 \\
\hline & $(0.016)$ & $(0.011)$ & $(0.008)$ & $(0.011)$ & $(0.022)$ & $(0.012)$ \\
\hline \multirow[t]{2}{*}{ Constant } & $0.865 * * *$ & $-0.270 * * *$ & $0.441 * * *$ & $0.264 * * *$ & -0.109 & -0.088 \\
\hline & $(0.121)$ & $(0.087)$ & $(0.057)$ & $(0.088)$ & $(0.160)$ & $(0.083)$ \\
\hline Observations & 4,003 & 4,003 & 3,857 & 4,003 & 4,003 & 4,003 \\
\hline Industry FE & Yes & Yes & Yes & Yes & Yes & Yes \\
\hline Year FE & Yes & Yes & Yes & Yes & Yes & Yes \\
\hline Adj. R-squared & 0.091 & 0.116 & 0.141 & 0.101 & 0.042 & 0.164 \\
\hline
\end{tabular}




\section{Table 4. Controlling for bank loan growth}

This table reports OLS estimates for the cross section of sample firms headquartered in the South Tyrol province with a CEO of Italian or Germanic origin as of the latest available year prior to 2016. The origin of the CEO is determined as illustrated in Appendix A. Dependent and control variables are computed as explained in Appendix B. Standard errors are corrected for heteroskedasticity. $* * *, * *$ and $*$ indicate statistical significance at the $1 \%, 5 \%$ and $10 \%$ levels, respectively.

\begin{tabular}{|c|c|c|c|c|c|}
\hline & $\begin{array}{l}\text { Total liabilities / } \\
\text { Total assets }\end{array}$ & $\begin{array}{l}\text { Total debt / } \\
\text { Total assets }\end{array}$ & $\begin{array}{l}\text { Accounts payable / } \\
\text { Total assets }\end{array}$ & Trade credit user & $\begin{array}{c}\text { Accounts receivable / } \\
\text { Total assets }\end{array}$ \\
\hline \multirow[t]{2}{*}{ CEO of Italian origin } & $0.027 * *$ & $0.021 * *$ & $0.018^{* *}$ & $0.050 * * *$ & 0.013 \\
\hline & $(0.013)$ & $(0.009)$ & $(0.008)$ & $(0.017)$ & $(0.009)$ \\
\hline \multirow[t]{2}{*}{ Firm size } & -0.006 & $0.020 * * *$ & -0.000 & $0.044 * * *$ & $0.006 * *$ \\
\hline & $(0.004)$ & $(0.003)$ & $(0.002)$ & $(0.005)$ & $(0.003)$ \\
\hline \multirow{2}{*}{ Asset tangibility } & -0.022 & $0.197 * * *$ & $-0.138 * * *$ & -0.037 & $-0.242 * * *$ \\
\hline & $(0.022)$ & $(0.019)$ & $(0.013)$ & $(0.031)$ & $(0.013)$ \\
\hline \multirow[t]{2}{*}{ Sales growth } & 0.012 & -0.000 & 0.008 & 0.018 & $0.019 * * *$ \\
\hline & $(0.009)$ & $(0.007)$ & $(0.007)$ & $(0.013)$ & $(0.007)$ \\
\hline \multirow[t]{2}{*}{ Investment } & -0.046 & $0.179 * * *$ & -0.024 & -0.048 & $-0.229 * * *$ \\
\hline & $(0.089)$ & $(0.058)$ & $(0.051)$ & $(0.102)$ & $(0.041)$ \\
\hline \multirow[t]{2}{*}{ Operating margin } & $-0.010 *$ & -0.008 & $-0.015 * * *$ & -0.005 & 0.001 \\
\hline & $(0.006)$ & $(0.006)$ & $(0.004)$ & $(0.008)$ & $(0.003)$ \\
\hline \multirow[t]{2}{*}{ Loan growth (municipality) } & 0.050 & $-0.081 * * *$ & 0.033 & 0.088 & $0.066^{* *}$ \\
\hline & $(0.041)$ & $(0.030)$ & $(0.026)$ & $(0.057)$ & $(0.030)$ \\
\hline \multirow[t]{2}{*}{ Firm age } & $-0.005 * * *$ & $-0.002 * * *$ & $-0.001 * * *$ & $-0.002 * *$ & -0.000 \\
\hline & $(0.000)$ & $(0.000)$ & $(0.000)$ & $(0.001)$ & $(0.000)$ \\
\hline \multirow[t]{2}{*}{ CEO age } & 0.002 & 0.001 & 0.002 & $0.010^{*}$ & $0.006^{* *}$ \\
\hline & $(0.003)$ & $(0.003)$ & $(0.002)$ & $(0.005)$ & $(0.002)$ \\
\hline \multirow{2}{*}{ CEO age squared } & -0.000 & -0.000 & -0.000 & $-0.000 *$ & $-0.000 * *$ \\
\hline & $(0.000)$ & $(0.000)$ & $(0.000)$ & $(0.000)$ & $(0.000)$ \\
\hline \multirow[t]{2}{*}{ CEO is male } & -0.011 & 0.008 & $-0.021 *$ & -0.002 & -0.016 \\
\hline & $(0.018)$ & $(0.012)$ & $(0.012)$ & $(0.025)$ & $(0.014)$ \\
\hline \multirow[t]{2}{*}{ Constant } & $0.900 * * *$ & $-0.247 * *$ & $0.285^{* * *} *$ & -0.176 & -0.107 \\
\hline & $(0.136)$ & $(0.111)$ & $(0.107)$ & $(0.201)$ & $(0.110)$ \\
\hline Observations & 3,035 & 3,035 & 3,035 & 3,035 & 3,035 \\
\hline Industry FE & Yes & Yes & Yes & Yes & Yes \\
\hline Year FE & Yes & Yes & Yes & Yes & Yes \\
\hline Adj. R-squared & 0.080 & 0.101 & 0.090 & 0.033 & 0.159 \\
\hline
\end{tabular}




\section{Table 5. Credit supply and the use of formal sources of credit during the financial crisis}

This table reports estimates for the panel of firms headquartered in the South Tyrol province with a CEO of Italian or Germanic origin over the years 2006-2015. CEO of Italian origin is a dummy variable which is constructed as illustrated in Appendix A. Crisis (Post crisis) is a dummy variable which equals one for the years 20082013 (2014-2015) and zero otherwise. All regressions include year fixed effects and controls for the following time-varying firm-specific variables: Firm size, asset tangibility, sales growth, investment, operating margin, age. Estimations in panel A include industry fixed effects and CEO characteristics: Age, age squared, gender. Estimations in panel B include firm fixed effects. Dependent and control variables are defined in Appendix B. Standard errors are clustered at the firm level. ***, ** and

$*$ indicate statistical significance at the $1 \%, 5 \%$ and $10 \%$ levels, respectively.

\begin{tabular}{|c|c|c|c|c|c|}
\hline & $\begin{array}{c}\text { Total liabilities / } \\
\text { Total assets } \\
\end{array}$ & $\begin{array}{l}\text { Total debt / } \\
\text { Total assets } \\
\end{array}$ & $\begin{array}{c}\text { Accounts payable / } \\
\text { Total assets } \\
\end{array}$ & Trade credit user & $\begin{array}{c}\text { Accounts receivable } / \\
\text { Total assets }\end{array}$ \\
\hline \multicolumn{6}{|c|}{ Panel A: Estimations with industry fixed effects } \\
\hline \multirow[t]{2}{*}{ CEO of Italian origin } & 0.013 & 0.003 & $0.018 * *$ & $0.055 * * *$ & $0.018 *$ \\
\hline & $(0.012)$ & $(0.011)$ & $(0.008)$ & $(0.014)$ & $(0.010)$ \\
\hline \multirow[t]{2}{*}{ CEO of Italian origin $*$ Crisis } & 0.012 & $0.024 * * *$ & 0.007 & $0.035 * * *$ & 0.013 \\
\hline & $(0.009)$ & $(0.009)$ & $(0.007)$ & $(0.013)$ & $(0.008)$ \\
\hline \multirow[t]{2}{*}{ CEO of Italian origin * Post crisis } & -0.000 & -0.004 & -0.002 & -0.004 & -0.006 \\
\hline & $(0.012)$ & $(0.012)$ & $(0.010)$ & $(0.019)$ & $(0.011)$ \\
\hline Observations & 27,844 & 27,844 & 27,844 & 27,844 & 27,844 \\
\hline Firm-level controls & Yes & Yes & Yes & Yes & Yes \\
\hline CEO characteristics & Yes & Yes & Yes & Yes & Yes \\
\hline Industry FE & Yes & Yes & Yes & Yes & Yes \\
\hline Firm FE & No & No & No & No & No \\
\hline Year FE & Yes & Yes & Yes & Yes & Yes \\
\hline \multirow[t]{2}{*}{ Adj. R-squared } & 0.127 & 0.112 & 0.153 & 0.060 & 0.218 \\
\hline & \multicolumn{5}{|c|}{ Panel B: Estimations with firm fixed effects } \\
\hline \multirow[t]{2}{*}{ CEO of Italian origin $*$ Crisis } & 0.011 & $0.023^{* * *}$ & -0.002 & $0.044 * * *$ & $0.016^{* *}$ \\
\hline & $(0.008)$ & $(0.008)$ & $(0.006)$ & $(0.012)$ & $(0.007)$ \\
\hline \multirow[t]{2}{*}{ CEO of Italian origin $*$ Post crisis } & $0.018^{*}$ & 0.004 & -0.006 & 0.023 & 0.007 \\
\hline & $(0.010)$ & $(0.010)$ & $(0.008)$ & $(0.018)$ & $(0.009)$ \\
\hline Observations & 27,845 & 27,845 & 27,845 & 27,845 & 27,845 \\
\hline Number of firms & 4,845 & 4,845 & 4,845 & 4,845 & 4,845 \\
\hline Firm-level controls & Yes & Yes & Yes & Yes & Yes \\
\hline CEO characteristics & No & No & No & No & No \\
\hline Industry FE & No & No & No & No & No \\
\hline Firm FE & Yes & Yes & Yes & Yes & Yes \\
\hline Year FE & Yes & Yes & Yes & Yes & Yes \\
\hline Adj. R-squared & 0.064 & 0.039 & 0.043 & 0.041 & 0.037 \\
\hline
\end{tabular}




\section{Table 6. Subsample analysis}

This table reports estimates for the cross-section of firms headquartered in the South Tyrol province with a CEO of Italian or Germanic origin as of the latest available year prior to 2016. The sample in panel A (B) $[C]\{D\}$ is restricted to those family firms whose CEO is a family member (is restricted to firms with total assets of up to $2 \mathrm{~m}$ euros) [excludes the construction, manufacturing, and energy sectors] \{excludes the manufacturing and wholesale and retail trade sectors $\}$. CEO of Italian origin is a dummy variable which is constructed as illustrated in Appendix A. All regressions include industry and year fixed effects and controls for firm size, asset tangibility, sales growth, investment, operating margin, age, and CEO characteristics (age, age squared, gender). Dependent and control variables are defined in Appendix B. Standard errors are corrected for heteroscedasticity. ***, ** and * indicate statistical significance at the $1 \%, 5 \%$ and $10 \%$ levels, respectively.

\begin{tabular}{|c|c|c|c|c|c|}
\hline & $\begin{array}{c}\text { Total liabilities / } \\
\text { Total assets } \\
\end{array}$ & $\begin{array}{l}\text { Total debt / } \\
\text { Total assets }\end{array}$ & $\begin{array}{c}\text { Accounts payable / } \\
\text { Total assets }\end{array}$ & Trade credit user & $\begin{array}{c}\text { Accounts receivable } \\
\text { Total assets }\end{array}$ \\
\hline \multicolumn{6}{|c|}{ Panel A: Family firms } \\
\hline \multirow[t]{2}{*}{ CEO of Italian origin } & $0.032 * *$ & 0.016 & $0.020 * *$ & $0.064 * * *$ & $0.022 *$ \\
\hline & $(0.015)$ & $(0.011)$ & $(0.009)$ & $(0.021)$ & $(0.011)$ \\
\hline Observations & 2,217 & 2,217 & 2,217 & 2,217 & 2,217 \\
\hline Adj. R-squared & 0.091 & 0.107 & 0.099 & 0.018 & 0.136 \\
\hline \multicolumn{6}{|c|}{ Panel B: Micro firms } \\
\hline \multirow[t]{2}{*}{ CEO of Italian origin } & $0.039 * *$ & 0.001 & $0.026 * * *$ & $0.074 * * *$ & $0.027 * *$ \\
\hline & $(0.015)$ & $(0.009)$ & $(0.009)$ & $(0.020)$ & $(0.011)$ \\
\hline Observations & 2,515 & 2,515 & 2,515 & 2,515 & 2,515 \\
\hline Adj. R-squared & 0.083 & 0.099 & 0.077 & 0.026 & 0.124 \\
\hline \multicolumn{6}{|c|}{ Panel C: Excluding culturally heterogeneous industries } \\
\hline \multirow[t]{2}{*}{ CEO of Italian origin } & $0.033 * *$ & 0.013 & $0.031 * * *$ & $0.091 * * *$ & $0.025 * *$ \\
\hline & $(0.015)$ & $(0.009)$ & $(0.009)$ & $(0.019)$ & $(0.010)$ \\
\hline Observations & 2,460 & 2,460 & 2,460 & 2,460 & 2,460 \\
\hline Adj. R-squared & 0.093 & 0.105 & 0.100 & 0.046 & 0.175 \\
\hline \multicolumn{6}{|c|}{ Panel D: Excluding importing industries } \\
\hline \multirow[t]{2}{*}{ CEO of Italian origin } & 0.022 & 0.007 & $0.017 * *$ & $0.045 * * *$ & 0.011 \\
\hline & $(0.014)$ & $(0.009)$ & $(0.007)$ & $(0.016)$ & $(0.008)$ \\
\hline Observations & 3,615 & 3,615 & 3,615 & 3,615 & 3,615 \\
\hline Adj. R-squared & 0.078 & 0.128 & 0.105 & 0.054 & 0.164 \\
\hline
\end{tabular}




\section{Table 7. Matching by size, industry, and location}

In panel A, each firm led by a CEO of Italian origin is matched with firms led by a CEO of Germanic origin of the same size and industry. In panel B, firms are additionally matched in terms of the administrative district where the firms are headquartered. All firms are headquartered in South Tyrol. CEO of Italian origin is a dummy variable which is constructed as illustrated in Appendix A. All regressions include the following variables: Firm size, asset tangibility, sales growth, investment, operating margin, age, industry and year fixed effects, and CEO characteristics (age, age squared, gender). Dependent and control variables are defined in Appendix B. Standard errors are robust to heteroscedasticity. ***,** and * indicate statistical significance at the $1 \%$, $5 \%$ and $10 \%$ levels, respectively.

\begin{tabular}{|c|c|c|c|c|c|}
\hline & $\begin{array}{c}\text { Total liabilities / } \\
\text { Total assets }\end{array}$ & $\begin{array}{l}\text { Total debt / } \\
\text { Total assets }\end{array}$ & $\begin{array}{c}\text { Accounts payable / } \\
\text { Total assets }\end{array}$ & Trade credit user & $\begin{array}{c}\text { Accounts receivable / } \\
\text { Total assets }\end{array}$ \\
\hline \multicolumn{6}{|c|}{ Panel A: Matched by industry and size } \\
\hline \multirow[t]{2}{*}{ CEO of Italian origin } & $0.028 * *$ & 0.006 & $0.018 * *$ & $0.053 * * *$ & $0.016 * *$ \\
\hline & $(0.011)$ & $(0.008)$ & $(0.007)$ & $(0.015)$ & $(0.008)$ \\
\hline Observations & 3,993 & 3,993 & 3,993 & 3,993 & 3,993 \\
\hline Adj. R-squared & 0.093 & 0.116 & 0.101 & 0.042 & 0.164 \\
\hline \multicolumn{6}{|c|}{ Panel B: Matched by industry, size, and location } \\
\hline CEO of Italian origin & $0.030 * * *$ & 0.007 & $0.048 * * *$ & $0.018 * *$ & $0.014 *$ \\
\hline & $(0.012)$ & $(0.008)$ & $(0.016)$ & $(0.007)$ & $(0.008)$ \\
\hline Observations & 3,633 & 3,633 & 3,633 & 3,633 & 3,633 \\
\hline Adj. R-squared & 0.084 & 0.111 & 0.036 & 0.094 & 0.158 \\
\hline
\end{tabular}




\section{Table 8. First stage instrumental variable estimation}

This table reports estimates from the first stage of instrumental variable regressions where the Italian origin of CEOs is instrumented with the proportion of Italian-speaking population in the municipality where the firm is headquartered. The sample includes firms headquartered in the South Tyrol province with a CEO of Italian or Germanic origin as of the latest available year prior to 2016. The origin of the CEO is determined as illustrated in Appendix A. Dependent and control variables are computed as explained in Appendix B. Standard errors are corrected for heteroskedasticity. ***, ** and * indicate statistical significance at the $1 \%, 5 \%$ and $10 \%$ levels, respectively.

\begin{tabular}{lc}
\hline & CEO is of Italian origin \\
\hline Percentage of Italians in the municipality of the firm's head quarters & $0.582^{* * *}$ \\
& $(0.022)$ \\
Firm size & $-0.031^{* * *}$ \\
& $(0.004)$ \\
Asset tangibility & 0.001 \\
Sales growth & $(0.025)$ \\
& $-0.031^{* * *}$ \\
Investment & $(0.011)$ \\
& 0.021 \\
Operating margin & $(0.078)$ \\
Firm age & 0.002 \\
& $(0.008)$ \\
CEO age & -0.000 \\
& $(0.000)$ \\
CEO age squared & $-0.010^{* *}$ \\
CEO is male & $(0.004)$ \\
& $0.000^{* * *}$ \\
Constant & $(0.000)$ \\
& $-0.041^{*}$ \\
Observations & $(0.022)$ \\
Industry FE & $0.872 * * *$ \\
Year FE & $(0.150)$ \\
R-squared & 4,003 \\
F-test statistic & Yes \\
\end{tabular}




\section{Table 9. Second stage instrumental variable estimation}

This table reports estimates from the second stage of instrumental variable regressions where the Italian origin of CEOs is instrumented with the proportion of Italian-speaking population in the municipality where the firm is headquartered. The sample includes firms headquartered in the South Tyrol province with a CEO of Italian or Germanic origin as of the latest available year prior to 2016. The origin of the CEO is determined as illustrated in Appendix A. Dependent and control variables are computed as explained in Appendix B. Standard errors are corrected for heteroskedasticity. $* * * * *$ and $*$ indicate statistical significance at the $1 \%, 5 \%$ and $10 \%$ levels, respectively.

\begin{tabular}{|c|c|c|c|c|c|}
\hline & $\begin{array}{c}\text { Total liabilities / } \\
\text { Total assets }\end{array}$ & $\begin{array}{l}\text { Total debt / } \\
\text { Total assets }\end{array}$ & $\begin{array}{c}\text { Accounts payable / } \\
\text { Total assets }\end{array}$ & Trade credit user & $\begin{array}{c}\text { Accounts receivable } / \\
\text { Total assets }\end{array}$ \\
\hline \multirow[t]{2}{*}{ CEO of Italian origin } & $0.138 * * *$ & $-0.063 * * *$ & $0.068 * * *$ & $0.141 * * *$ & $0.055^{* * *}$ \\
\hline & $(0.029)$ & $(0.022)$ & $(0.018)$ & $(0.040)$ & $(0.020)$ \\
\hline \multirow[t]{2}{*}{ Firm size } & -0.002 & $0.018 * * *$ & 0.002 & $0.053 * * *$ & $0.007 * * *$ \\
\hline & $(0.004)$ & $(0.002)$ & $(0.002)$ & $(0.004)$ & $(0.002)$ \\
\hline \multirow[t]{2}{*}{ Asset tangibility } & -0.007 & $0.212 * * *$ & $-0.143 * * *$ & -0.030 & $-0.232 * * *$ \\
\hline & $(0.020)$ & $(0.017)$ & $(0.011)$ & $(0.027)$ & $(0.011)$ \\
\hline \multirow[t]{2}{*}{ Sales growth } & 0.012 & -0.005 & 0.010 & 0.016 & $0.019 * * *$ \\
\hline & $(0.009)$ & $(0.007)$ & $(0.006)$ & $(0.012)$ & $(0.006)$ \\
\hline \multirow[t]{2}{*}{ Investment } & -0.049 & $0.189 * * *$ & -0.013 & 0.072 & $-0.190 * * *$ \\
\hline & $(0.074)$ & $(0.052)$ & $(0.042)$ & $(0.085)$ & $(0.033)$ \\
\hline \multirow[t]{2}{*}{ Operating margin } & $-0.014 * *$ & $-0.013^{* *}$ & $-0.016 * * *$ & -0.013 & -0.002 \\
\hline & $(0.006)$ & $(0.005)$ & $(0.003)$ & $(0.008)$ & $(0.003)$ \\
\hline \multirow[t]{2}{*}{ Firm age } & $-0.005 * * *$ & $-0.002 * * *$ & $-0.001 * * *$ & $-0.002 * * *$ & -0.000 \\
\hline & $(0.000)$ & $(0.000)$ & $(0.000)$ & $(0.001)$ & $(0.000)$ \\
\hline \multirow[t]{2}{*}{ CEO age } & 0.004 & 0.002 & $0.003 *$ & $0.009 * *$ & $0.005 * * *$ \\
\hline & $(0.003)$ & $(0.002)$ & $(0.002)$ & $(0.004)$ & $(0.002)$ \\
\hline \multirow{2}{*}{ CEO age squared } & $-0.000 *$ & -0.000 & $-0.000 * *$ & $-0.000^{*}$ & $-0.000 * * *$ \\
\hline & $(0.000)$ & $(0.000)$ & $(0.000)$ & $(0.000)$ & $(0.000)$ \\
\hline \multirow[t]{2}{*}{ CEO is male } & -0.000 & 0.009 & -0.016 & 0.017 & -0.006 \\
\hline & $(0.016)$ & $(0.011)$ & $(0.011)$ & $(0.023)$ & $(0.012)$ \\
\hline \multirow[t]{2}{*}{ Constant } & $0.754 * * *$ & $-0.199 * *$ & $0.214 * *$ & -0.198 & -0.126 \\
\hline & $(0.122)$ & $(0.088)$ & $(0.088)$ & $(0.165)$ & $(0.084)$ \\
\hline Observations & 4,003 & 4,003 & 4,003 & 4,003 & 4,003 \\
\hline Industry FE & Yes & Yes & Yes & Yes & Yes \\
\hline Year FE & Yes & Yes & Yes & Yes & Yes \\
\hline
\end{tabular}




\section{Table 10. Additional forms of financing}

This table reports OLS estimates for the cross section of sample firms headquartered in the South Tyrol province with a CEO of Italian or Germanic origin as of the latest available year prior to 2016. Only firms that provide information in their balance sheet on retained earnings and shareholders' loans are included. The origin of the CEO is determined as illustrated in Appendix A. Dependent and control variables are computed as explained in Appendix B. Standard errors are corrected for heteroskedasticity. $* * *, * *$ and $*$ indicate statistical significance at the $1 \%, 5 \%$ and $10 \%$ levels, respectively.

\begin{tabular}{lcc}
\hline & Retained earnings / & Shareholders' loans / \\
Total assets & Total assets \\
\hline CEO of Italian origin & $-0.015^{* *}$ & 0.011 \\
& $(0.008)$ & $(0.007)$ \\
Firm size & $0.020^{* * *}$ & $-0.008^{* * * *}$ \\
& $(0.003)$ & $(0.002)$ \\
Asset tangibility & -0.006 & $0.072^{* * *}$ \\
& $(0.014)$ & $(0.017)$ \\
Sales growth & 0.007 & -0.004 \\
& $(0.007)$ & $(0.008)$ \\
Investment & 0.053 & -0.045 \\
& $(0.046)$ & $(0.041)$ \\
Operating margin & $0.017^{* * *}$ & $0.019^{* * *}$ \\
& $(0.005)$ & $(0.007)$ \\
Firm age & $0.000^{* *}$ & $-0.001 * * *$ \\
& $(0.000)$ & $(0.000)$ \\
CEO age & -0.003 & $-0.006^{* * *}$ \\
& $(0.002)$ & $(0.002)$ \\
CEO age squared & 0.000 & $0.000^{* * *}$ \\
CEO is male & $(0.000)$ & $(0.000)$ \\
& -0.003 & 0.009 \\
Constant & $(0.011)$ & $(0.010)$ \\
& $-0.224^{* * *}$ & $0.206 * * *$ \\
Observations & $(0.064)$ & $(0.066)$ \\
Industry FE & 3,432 & 2,491 \\
Year FE & Yes & Yes \\
Adj. R-squared & Yes & Yes \\
& 0.051 & 0.073 \\
\hline
\end{tabular}


Language groups in South Tyrol - Census 2011

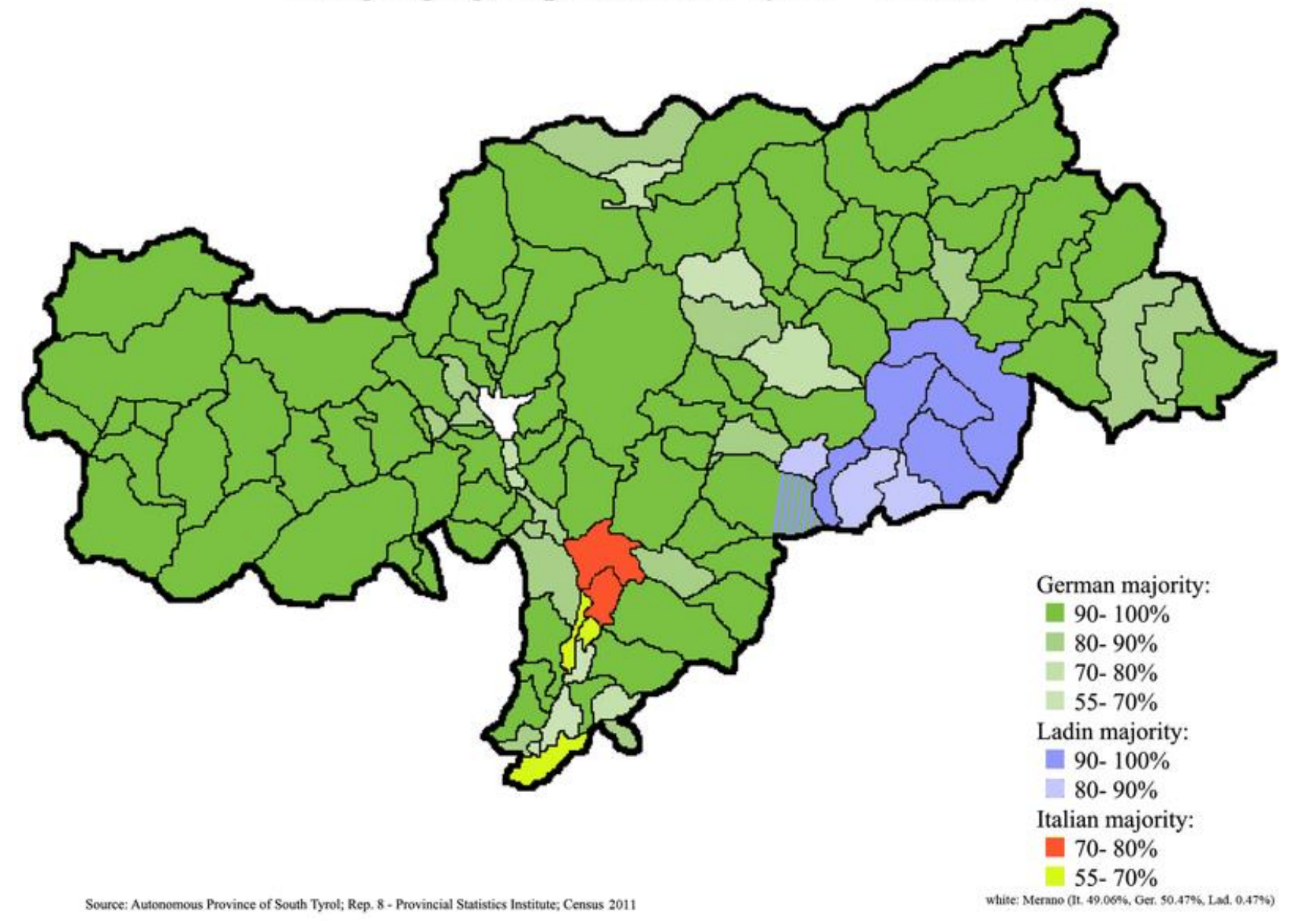


Figure 2. Cultural origin by industry

Cultural origin by industry (\%)

0.25

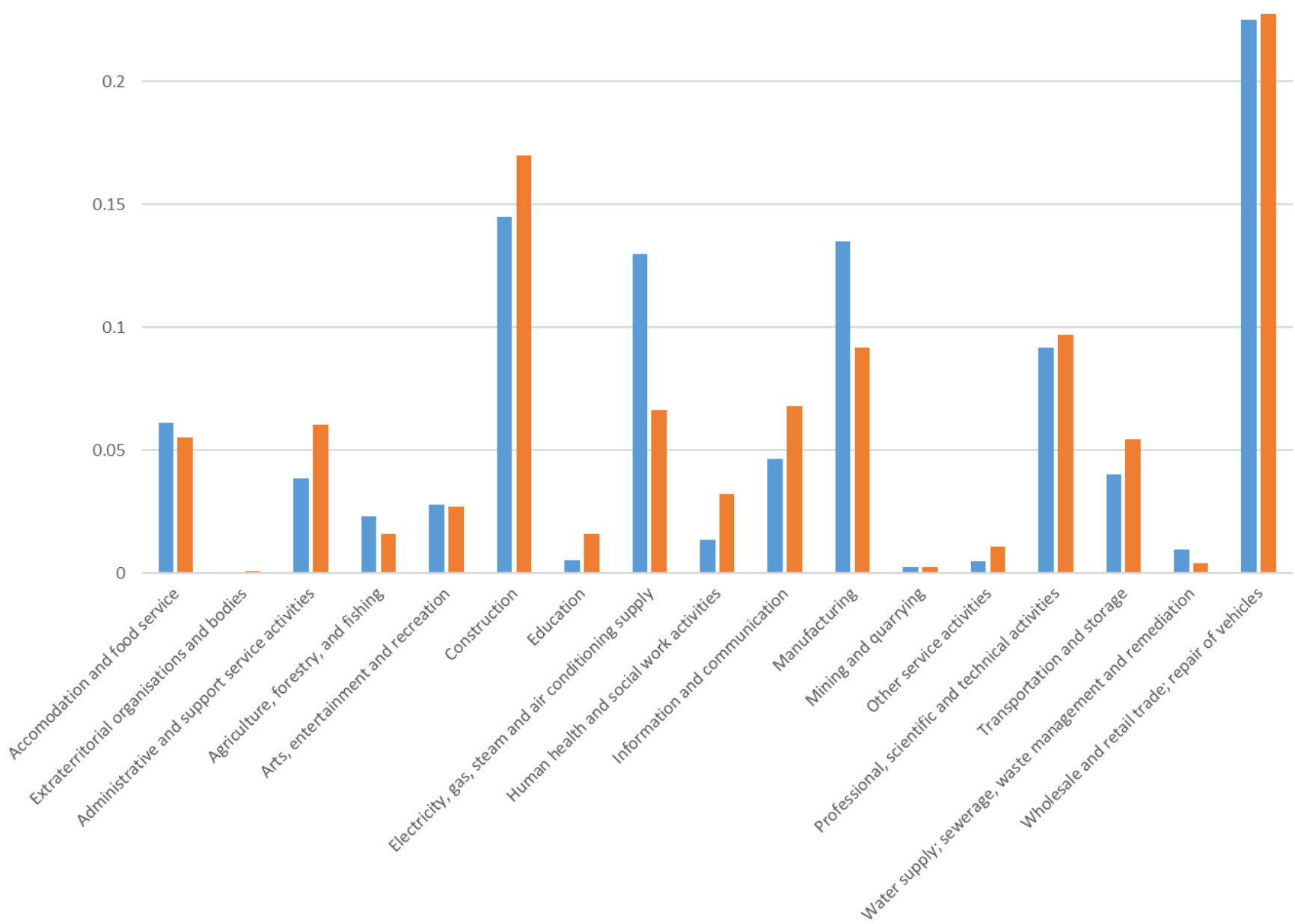

- Germans I Italians 


\section{Appendix A. Manager classification}

We classify a CEO as of Italian origin if all his/her given names and surname are Italian. We classify a CEO as of Germanic origin if all his/her given names and surname are Germanic. If the given name is common to both Italian and Germanic languages, we classify the CEO origin based on the surname. Foreign CEOs and CEOs with discordant given names and surname are excluded. The following are some examples of CEO classification.

\begin{tabular}{lll}
\hline Name and surname & Criteria & Classification \\
\hline Claudio La Spisa & Italian given name and surname & Italian \\
Georg Koessler & Germanic given name and surname & Germanic \\
Marco Fuchs & Italian or Germanic given name; Germanic surname & Germanic \\
Marco Iori & Italian or Germanic given name; Italian surname & Italian \\
Paolo Stocker & Italian given name; Germanic surname & Excluded \\
Guenther Longo & Germanic given name; Italian surname & Excluded \\
Youjun Luan & Foreign given name and surname & Excluded \\
\hline
\end{tabular}


Appendix B. Variable definitions

\begin{tabular}{|c|c|c|}
\hline Variable & Calculation & Source \\
\hline CEO of Italian origin & $\begin{array}{l}\text { Dummy }=1(=0) \text { if manager is of Italian } \\
\text { (Germanic) origin }\end{array}$ & $\begin{array}{l}\text { Lists of Italian and German/Austrian } \\
\text { most common names and surnames. } \\
\text { Telephone directories }\end{array}$ \\
\hline $\begin{array}{l}\text { Total liabilities / } \\
\text { Total assets }\end{array}$ & $\begin{array}{l}\text { (Non-current liabilities + current liabilities) / } \\
\text { Total assets }\end{array}$ & Orbis BvD \\
\hline $\begin{array}{l}\text { Total debt / } \\
\text { Total assets }\end{array}$ & (Loans + long term debt) / Total assets & Orbis BvD \\
\hline Cash / Total assets & Cash and cash equivalent / Total assets & Orbis BvD \\
\hline $\begin{array}{l}\text { Accounts payable / } \\
\text { Total assets }\end{array}$ & Creditors / Total assets & Orbis BvD \\
\hline Trade credit user & Dummy $=1$ if Creditors $>0$ & Orbis BvD \\
\hline $\begin{array}{l}\text { Accounts receivable / } \\
\text { Total assets }\end{array}$ & Debtors / Total assets & Orbis BvD \\
\hline Firm size & $\ln$ (total assets) & Orbis BvD \\
\hline Asset tangibility & Tangible fixed assets / Total assets & Orbis BvD \\
\hline Sales growth & $\ln ($ sales $)-\ln (\text { sales })_{-1}$ & Orbis BvD \\
\hline Investment & $\begin{array}{l}\text { (Tangible fixed assets }- \text { tangible fixed } \\
\text { assets }-1+\text { depreciation) / Total assets }\end{array}$ & Orbis BvD \\
\hline Operating margin & Ebitda / Sales & Orbis BvD \\
\hline Firm age & Firm age in years & Orbis BvD \\
\hline CEO age & CEO age in years & Orbis BvD \\
\hline CEO is male & Dummy $=1$ if CEO is male & Orbis BvD \\
\hline $\begin{array}{l}\text { Loan growth } \\
\text { (municipality) }\end{array}$ & $\begin{array}{l}\ln (\text { total bank loans in municipality) }-\ln (\text { total } \\
\text { bank loans in municipality) })_{-1}\end{array}$ & Bank of Italy statistical database \\
\hline Instrumental variable & $\begin{array}{l}\text { Proportion of Italian-speaking population in } \\
\text { the municipality where firm is headquartered }\end{array}$ & Italian census 2011 \\
\hline $\begin{array}{l}\text { Retained earnings / } \\
\text { Total assets }\end{array}$ & Retained earnings / Total assets & Aida BvD \\
\hline $\begin{array}{l}\text { Shareholders' loans / } \\
\text { Total assets }\end{array}$ & Shareholders' loans / Total assets & Aida BvD \\
\hline
\end{tabular}




\section{Appendix C. Regressions without potentially endogenous control variables}

This table reports OLS estimates for the cross section of sample firms headquartered in the South Tyrol province with a CEO of Italian or Germanic origin CEO of Italian or Germanic origin as of the latest available year prior to 2016 after removing potentially endogenous control variables. The origin of the CEO is determined as illustrated in Appendix A. Dependent and control variables are computed as explained in Appendix B. Standard errors are corrected for heteroskedasticity. ***, $* *$ and $*$ indicate statistical significance at the $1 \%, 5 \%$ and $10 \%$ levels, respectively.

\begin{tabular}{|c|c|c|c|c|c|}
\hline & $\begin{array}{c}\text { Total liabilities / } \\
\text { Total assets }\end{array}$ & $\begin{array}{l}\text { Total debt / } \\
\text { Total assets }\end{array}$ & $\begin{array}{l}\text { Accounts Payable / } \\
\text { Total assets }\end{array}$ & Trade Credit User & $\begin{array}{c}\text { Accounts Receivable / } \\
\text { Total assets }\end{array}$ \\
\hline \multirow[t]{2}{*}{ CEO of Italian origin } & $0.033 * * *$ & $-0.023 * * *$ & $0.028 * * *$ & $0.026^{*}$ & $0.036^{* * *}$ \\
\hline & $(0.011)$ & $(0.008)$ & $(0.007)$ & $(0.015)$ & $(0.009)$ \\
\hline \multirow[t]{2}{*}{ Firm age } & $-0.006 * * *$ & $-0.000 *$ & $-0.002 * * *$ & -0.001 & $-0.001 * * *$ \\
\hline & $(0.000)$ & $(0.000)$ & $(0.000)$ & $(0.001)$ & $(0.000)$ \\
\hline \multirow[t]{2}{*}{ CEO age } & 0.002 & 0.002 & 0.003 & $0.009 * *$ & $0.006 * * *$ \\
\hline & $(0.003)$ & $(0.002)$ & $(0.002)$ & $(0.004)$ & $(0.002)$ \\
\hline \multirow[t]{2}{*}{ CEO age squared } & -0.000 & -0.000 & $-0.000 *$ & -0.000 & $-0.000 * * *$ \\
\hline & $(0.000)$ & $(0.000)$ & $(0.000)$ & $(0.000)$ & $(0.000)$ \\
\hline \multirow[t]{2}{*}{ Constant } & $0.781 * * *$ & $0.116^{*}$ & $0.093 *$ & $0.442 * * *$ & 0.029 \\
\hline & $(0.084)$ & $(0.065)$ & $(0.050)$ & $(0.117)$ & $(0.056)$ \\
\hline Observations & 4,003 & 4,003 & 4,003 & 4,003 & 4,003 \\
\hline Adj. R-squared & 0.072 & 0.002 & 0.018 & 0.004 & 0.007 \\
\hline
\end{tabular}




\section{Appendix D. Italian Board of Directors and firm financing choices}

This table reports estimates for the cross section of firms headquartered in the South Tyrol province with a board of directors of Italian or Germanic origin as of the latest available year prior to 2016. BoD of Italian origin is a dummy variable equal to one if the majority of the members of the Board of Directors is of Italian origin, zero otherwise. All regressions include industry and year fixed effects. Dependent and control variables are defined in Appendix B. Standard errors are robust to heteroscedasticity. $* * *, * *$ and $*$ indicate statistical significance at the $1 \%, 5 \%$ and $10 \%$ levels, respectively.

\begin{tabular}{|c|c|c|c|c|c|}
\hline & $\begin{array}{c}\text { Total liabilities / } \\
\text { Total assets }\end{array}$ & $\begin{array}{l}\text { Total debt / } \\
\text { Total assets }\end{array}$ & $\begin{array}{c}\text { Accounts Payable / } \\
\text { Total assets }\end{array}$ & Trade Credit User & $\begin{array}{c}\text { Accounts Receivable / } \\
\text { Total assets }\end{array}$ \\
\hline \multirow[t]{2}{*}{ BoD of Italian origin } & $0.036 * * *$ & 0.013 & $0.020 * * *$ & $0.058 * * *$ & $0.020 * *$ \\
\hline & $(0.012)$ & $(0.008)$ & $(0.007)$ & $(0.016)$ & $(0.009)$ \\
\hline \multirow[t]{2}{*}{ Firm size } & -0.005 & $0.021 * * *$ & 0.000 & $0.052 * * *$ & $0.005 * *$ \\
\hline & $(0.004)$ & $(0.002)$ & $(0.002)$ & $(0.004)$ & $(0.002)$ \\
\hline \multirow{2}{*}{ Asset tangibility } & -0.011 & $0.214 * * *$ & $-0.141 * * *$ & -0.031 & $-0.232 * * *$ \\
\hline & $(0.020)$ & $(0.017)$ & $(0.011)$ & $(0.027)$ & $(0.011)$ \\
\hline \multirow[t]{2}{*}{ Sales growth } & 0.008 & -0.004 & 0.009 & 0.014 & $0.019 * * *$ \\
\hline & $(0.009)$ & $(0.007)$ & $(0.006)$ & $(0.012)$ & $(0.006)$ \\
\hline \multirow[t]{2}{*}{ Investment } & -0.065 & $0.217 * * *$ & -0.016 & 0.096 & $-0.173 * * *$ \\
\hline & $(0.076)$ & $(0.053)$ & $(0.043)$ & $(0.087)$ & $(0.034)$ \\
\hline \multirow[t]{2}{*}{ Operating margin } & $-0.014^{* *}$ & $-0.016 * * *$ & $-0.016^{* * *}$ & $-0.014 *$ & -0.002 \\
\hline & $(0.006)$ & $(0.006)$ & $(0.003)$ & $(0.008)$ & $(0.002)$ \\
\hline \multirow[t]{2}{*}{ Firm age } & $-0.005^{* * *}$ & $-0.002 * * *$ & $-0.001 * * *$ & $-0.003 * * *$ & 0.000 \\
\hline & $(0.000)$ & $(0.000)$ & $(0.000)$ & $(0.001)$ & $(0.000)$ \\
\hline \multirow[t]{2}{*}{ CEO age } & 0.002 & 0.002 & 0.002 & $0.010 * *$ & $0.005 * *$ \\
\hline & $(0.003)$ & $(0.002)$ & $(0.002)$ & $(0.004)$ & $(0.002)$ \\
\hline \multirow[t]{2}{*}{ CEO age squared } & -0.000 & -0.000 & -0.000 & $-0.000 *$ & $-0.000 * *$ \\
\hline & $(0.000)$ & $(0.000)$ & $(0.000)$ & $(0.000)$ & $(0.000)$ \\
\hline \multirow[t]{2}{*}{ CEO is male } & -0.010 & 0.014 & $-0.024 * *$ & 0.013 & -0.013 \\
\hline & $(0.016)$ & $(0.011)$ & $(0.011)$ & $(0.023)$ & $(0.013)$ \\
\hline \multirow[t]{2}{*}{ Constant } & $0.881 * * *$ & $-0.284 * * *$ & $0.281 * * *$ & -0.171 & -0.078 \\
\hline & $(0.126)$ & $(0.090)$ & $(0.092)$ & $(0.167)$ & $(0.086)$ \\
\hline Observations & 3,779 & 3,779 & 3,779 & 3,779 & 3,779 \\
\hline Industry FE & Yes & Yes & Yes & Yes & Yes \\
\hline Year FE & Yes & Yes & Yes & Yes & Yes \\
\hline Adj. R-squared & 0.088 & 0.113 & 0.099 & 0.043 & 0.163 \\
\hline
\end{tabular}




\section{Appendix E. Credit supply and the use of formal sources of credit for family firms in Bolzano city during the financial crisis}

This table reports estimates for the panel of family firms headquartered in the city of Bolzano in the South Tyrol province over the years 2006-2015. CEO of Italian origin is a dummy variable which is constructed as illustrated in Appendix A. Crisis (Post crisis) is a dummy variable which equals one for the years 2008-2013 (2014-2015) and zero otherwise. All regressions include year fixed effects and control for the following time-varying firm-specific variables: Firm size, asset tangibility, sales growth, investment, operating margin, age. Estimations in panel A also include industry fixed effects and CEO characteristics (age, age squared, gender). Estimations in panel B include firm fixed effects. Dependent and control variables are defined in Appendix B. Standard errors are clustered at the firm level. ***,** and $*$ indicate statistical significance at the $1 \%, 5 \%$ and $10 \%$ levels, respectively.

\begin{tabular}{|c|c|c|c|c|c|}
\hline & $\begin{array}{c}\text { Total liabilities / } \\
\text { Total assets }\end{array}$ & $\begin{array}{l}\text { Total debt / } \\
\text { Total assets }\end{array}$ & $\begin{array}{c}\text { Accounts Payable / } \\
\text { Total assets }\end{array}$ & Trade Credit User & $\begin{array}{c}\text { Accounts Receivable } / \\
\text { Total assets }\end{array}$ \\
\hline \multicolumn{6}{|c|}{ Panel A: Industry fixed effects } \\
\hline \multirow[t]{2}{*}{ CEO of Italian origin } & 0.001 & -0.017 & $0.027 *$ & $0.045^{*}$ & 0.017 \\
\hline & $(0.018)$ & $(0.018)$ & $(0.016)$ & $(0.024)$ & $(0.018)$ \\
\hline \multirow[t]{2}{*}{ CEO of Italian origin $*$ Crisis } & 0.029 & $0.055 * * *$ & -0.001 & 0.003 & 0.023 \\
\hline & $(0.020)$ & $(0.019)$ & $(0.017)$ & $(0.028)$ & $(0.020)$ \\
\hline CEO of Italian origin $*$ Post & -0.020 & 0.008 & 0.001 & 0.032 & 0.016 \\
\hline crisis & $(0.029)$ & $(0.026)$ & $(0.023)$ & $(0.044)$ & $(0.027)$ \\
\hline Observations & 4,255 & 4,255 & 4,255 & 4,255 & 4,255 \\
\hline Firm-level controls & Yes & Yes & Yes & Yes & Yes \\
\hline CEO characteristics & Yes & Yes & Yes & Yes & Yes \\
\hline Industry FE & Yes & Yes & Yes & Yes & Yes \\
\hline Firm FE & No & No & No & No & No \\
\hline Year FE & Yes & Yes & Yes & Yes & Yes \\
\hline \multirow[t]{2}{*}{ Adj. R-squared } & 0.162 & 0.127 & 0.118 & 0.037 & 0.173 \\
\hline & \multicolumn{5}{|c|}{ Panel B: Firm fixed effects } \\
\hline \multirow[t]{2}{*}{ CEO of Italian origin $*$ Crisis } & 0.006 & $0.044 * * *$ & -0.009 & 0.030 & $0.037 * *$ \\
\hline & $(0.016)$ & $(0.017)$ & $(0.015)$ & $(0.028)$ & $(0.015)$ \\
\hline CEO of Italian origin $*$ Post & -0.008 & -0.001 & -0.014 & 0.043 & $0.036^{*}$ \\
\hline crisis & $(0.021)$ & $(0.021)$ & $(0.020)$ & $(0.041)$ & $(0.021)$ \\
\hline Observations & 4,255 & 4,255 & 4,255 & 4,255 & 4,255 \\
\hline Firm-level controls & Yes & Yes & Yes & Yes & Yes \\
\hline CEO characteristics & No & No & No & No & No \\
\hline Industry FE & No & No & No & No & No \\
\hline Firm FE & Yes & Yes & Yes & Yes & Yes \\
\hline Year FE & Yes & Yes & Yes & Yes & Yes \\
\hline Adj. R-squared & 0.091 & 0.055 & 0.050 & 0.034 & 0.033 \\
\hline
\end{tabular}

